\title{
Helper and Suppressor T Cell Factors
}

\author{
R. N. Germain and B. Benacerraf \\ Department of Pathology, Harvard Medical School, Boston, Ma. 02115, USA
}

\section{Introduction}

The emerging view of the immune system is that of a collection of lymphocyte networks, in which the cellular elements are related by a common set of antigen reactivities or the possession of a distinct subset of antigen receptors $[14,28,59]$. Each network involves two separate components, the first responsible for effector function, and the second consisting of the regulatory apparatus for controlling the effector activity. Over the past few years, great strides have been made in identifying the cells involved in immune regulation. It is clear that $\mathrm{T}$ lymphocytes play a crucial role in this process, and can be divided generally according to whether their activity is to amplify overall effector function, or to dampen (suppress) immunity. T cell subsets with distinct differentiation (cell surface) markers, tissue localization, drug sensitivities, and lifetimes have been found to mediate these various effects $[15,16$, $45,47]$. In addition, there is growing evidence that the regulatory capacity of these $T$

\footnotetext{
Abbreviations: $A B A$ azobenzenearsonate; $B G G$ bovine gamma globulin; $C$ complement; $C G A T$ common idiotype of anti-GAT antibodies; $C_{H}$ constant region of immunoglobulin heavy chain; $C_{L}$ constant region of immunoglobulin light chain; $C R I$ cross-reactive idiotype of anti-ABA antibodies of $\mathrm{A} / \mathrm{J}$ mice; $C T L$ cytolytic T lymphocytes; $D N P$ dinitrophenyl; $E A$ egg albumin; $G A$ random copolymer of L-glutamic acid ${ }^{60}$-L-alanine ${ }^{40}$; GATrandom copolymer of L-glutamic acid ${ }^{60}$-L-alanine ${ }^{30}$-L-tyrosine ${ }^{10}$; $G L \emptyset$ random copolymer of L-glutamic acid ${ }^{56}$-L-lysine ${ }^{35}$-L-phenylalanine ${ }^{9} ; G T$ random copolymer of L-glutamic acid ${ }^{50}$-L-tyrosine ${ }^{50} ; H \gamma G$ human gamma globulin; $K L H$ keyhole limpet hemocyanin; $M B S A$ methylated bovine serum albumin; $M H C$ major histocompatibility complex; $M L R$ mixed lymphocyte response; $M \emptyset$ macrophage(s); $O X$ oxazalone; $P C 1$ picryl chloride = trinitrochlorobenzene; $P E C$ peritoneal exudate cells; PFC plaque forming cells; (Phe, G)- $A-L$ (poly-L-phenylalanine, Lglutamic acid)-poly-DL-alanine-poly-L-lysine; $P S A$ picryl sulfonic acid =TNBS - trinitrobenzene sulfonic acid; $T_{a} F$ T cell derived augmenting (enhancing) factor; $(T, G)-A-L$ poly-L-tyrosine, $\mathrm{L}$-glutamic acid)-poly-DL-alanine-poly-L-lysine; ( $T, G)$ pro- $L$ (poly-L-trysine, L-glutamic acid)-poly-L-prolinepoly-L-lysine; $T_{H}$ helper $\mathrm{T}$ lymphocyte; $T_{H} F \mathrm{~T}$ cell derived helper factor; $T_{S}$ suppressor $\mathrm{T}$ lymphocyte; $T_{S} F \mathrm{~T}$ cell derived suppressor factor; $T_{S_{2}}$ suppressor $\mathrm{T}$ lymphocyte induced by $\mathrm{T}_{\mathrm{S}} \mathrm{F} ; V_{H}$ variable region of the heavy chain of immunoglobulin; $X R$ X-irradiated;
} 
lymphocytes resides largely in a closely related family of soluble macromolecular factors endowed with the ability to either mediate the activity ascribed to the parental $\mathrm{T}$ cell, or in fact, to induce lymphocytes producing such end-stage regulatory molecules $[34,38,102]$.

The present review is an attempt to summarize current information on one particular type of $\mathrm{T}$ cell regulatory macromolecule, namely the family of factors bearing determinants coded for by major histocompatibility complex (MHC) linked genes. This is done, not to diminish the importance of the myriad of non-MHC coded lymphokines, but to restrict the discussion to a manageable size, in the hope that a meaningful analysis of at least this small area of immunologic research can be made. Toward this end, we will review, in a succinct manner, the data available on $T$ derived helper and suppressor factors in the various model systems being studied, and then attempt to integrate the seemingly disparate findings into a scheme which can serve as a basis for hypotheses testing. Finally, we will speculate briefly on the in vivo significance of these $T$ cell factors and the immune pathways in which they are involved.

\section{Helper Factors}

\section{A. Acting on $B$ Cell Responses}

1. In vivo Studies on Helper Factors Specific for Branched Chain Synthetic Polypeptides. Synthetic polypeptide antigens such as (T, G)-A - L [116] have played a major role in studies on soluble helper factors. Immune responses to these compounds in animals of responder Ir genotype are characterized by both IgM and IgG antibody production and $\mathrm{T}$ cell immunity. Ir low responder mice make either no antibody or IgM only, depending on the batch of antigen used, and these animals never show classic in vivo $\mathrm{T}$ cell immunity $[82,83,120]$.

Using (T, G)-A - L, Taussig first reported in 1974 on the existence of soluble, T cell derived materials from responder strain mice able to replace specific helper function in vivo for antibody responses [139]. The basic experimental model used for this and subsequent studies on in vivo active $(T, G)-A-L T_{H} F$ involved priming thymocytes in lethally X-irradiated (XR) hosts in the presence of (T, G)-A-L, then removing these "activated $T$ cells" and culturing them for $6-8 \mathrm{~h}$ in vitro at high cell density in the presence of antigen. The supernatant of these cells was then assayed for helper function by admixture with unprimed bone marrow cells plus antigen, followed by adoptive transfer to an XR syngeneic recipient. Either the specific plaque response or serum antibody was assayed 12 or more days after transfer. Taussig demonstrated in his initial experiment that while bone marrow (" $\mathrm{B}$ " cells) plus antigen gave few anti-(T, G)-A-L IgM plaque forming cells (PFC), the addition of the supernatant $T$ cell factor led to the same level of PFC as did addition of unprimed $T$ cells. This factor appeared to be specific in that it did not augment anti-sheep red blood cell responses under the same conditions, and it would only be released from ( $T, G)-A-L$ primed cells recultured with (T, G)-A - L. This factor could, however, help responses to the related antigens (Phe, $G$ )- $A-L$ and $(H, G)-A$ - L, but not ( $T, G)$-pro-L, thus distinguishing the functional specificity of this factor from the fine specificity of Ir gene control of responsiveness to these polymers [56]. 
Immunochemical analysis of this factor involved affinity chromatography of the soluble material on antigen or antibody conjugated gel beads, followed by bioassay of the material passing through the adsorbent, and in most later studies, of the material eluted from the adsorbent. Since the factor passed through adsorbents specific for immunoglobulin determinants, the active principle did not seem to be conventional antibody [140]. Nonetheless, the factor appeared to possess an antigen-combining site, since it bound to (T, G)-A - L conjugated beads [96]; the actual antigen specificity of this $T_{H} F$ appears to be $G-A-L$, since $(T, G)-A-L$, (Phe,G)-A - L, (H,G)-A - L, and G-A - L, but not A $-\mathrm{L}$ immunoadsorbents bind $(T, G)-A-L T_{H} F[56]$. These binding data are consistent with the functional specificity described above. Perhaps the most intriguing data concerned the effects of passing ( $T, G)-A-L T_{H} F$ over immunoadsorbents prepared from anti-H-2 alloantisera. Such studies showed complete removal of helper activity from the factor preparation when the allo-antiserum used was directed against the $\mathrm{H}-2$ haplotype of the factor producing strain $[95,140,142]$. Further experiments provided evidence suggesting that it was the anti-Ia and not anti-K or D antibodies which were important in removing the $\mathrm{T}_{\mathrm{H}} \mathrm{F}$. These data were obtained by absorbing B10.A anti-B10.D2 serum with B10.D2 erythrocytes to remove selctively anti-K end activity and leave anti-Ia activity. Such absorbed serum bound to gel still removed $(T, G)-A-L T_{H} F$. derived from H-2 ${ }^{d}$ mice. Similarly A.TH anti-A.TL (anti-Ia ${ }^{k}$ ) antiserum removed activity from $\mathrm{H}-2^{\mathrm{k}}$ derived $(\mathrm{T}, \mathrm{G})-\mathrm{A}-\mathrm{L} \mathrm{T}_{\mathrm{H}} \mathrm{F}$ [142]. Thus, these studies established for the first time that a $\mathrm{T}$ cell derived product active in regulating the immune response possessed both antigen binding activity and H-2 (I) coded determinants. Later studies on $(\mathrm{T}, \mathrm{G})$-pro-L $\mathrm{T}_{\mathrm{H}} \mathrm{F}$ confirmed that this class of $\mathrm{T}$ cell factor bears I-A subregion coded determinants [57]. Gel filtration indicated that the active moiety in the factor preparation was approximately 50000 daltons [95], consistent with the immunoadsorbent studies indicating that the $T_{H} F$ was not a conventional immunoglobulin.

More recently, Mozes and Haimovich [94] have reported that (T, G) -A - L T $\mathrm{T}_{\mathrm{H}} \mathrm{F}$ does share idiotypic determinants with antibodies of the same specificity. They produced anti-idiotypic antibodies to $(T, G)-A-L$ antibody from two strains with different heavy chain linkage groups, and showed that these anti-idiotypic reagents were restricted to binding anti- $(\mathrm{T}, \mathrm{G})-\mathrm{A}-\mathrm{L}$ antibodies from the original donor strain or Ig $\mathrm{C}_{\mathrm{H}}$ matched strains. After conjugation to Sepharose, these anti-idiotypic antibodies bound $(\mathrm{T}, \mathrm{G})-\mathrm{A}-\mathrm{L} \mathrm{T}_{\mathrm{H}} \mathrm{F}$ only from strains with the appropriate allotype markers.

Taussig and collaborators also employed $\mathrm{T}_{\mathrm{H}} \mathrm{F}$ to explore the basis for Ir gene control of $(T, G)-A-L$ humoral responses. After demonstrating that helper factors of this type acted across $\mathrm{H}-2$ barriers by using (Phe, G)-A $-\mathrm{L}$ specific material derived from a series of $B 10$ congeneic strains [142], they tested putative $T_{H} F$ from cells of mice of several H-2 haplotypes on responder strain bone marrow cells. Conversely, known active $T_{H} F$ was tested using bone marrow cells from a variety of non-responder strains. These studies showed that non-responders fall into three broad categories: (a) those unable to produce $\mathrm{T}_{\mathrm{H}} \mathrm{F}$, but able to respond to it, (b) those producing $\mathrm{T}_{\mathrm{H}} \mathrm{F}$, but not responding to it, and (c) those with both defects $[55,93,96$, 141]. These data are consistent with earlier limiting dilution studies showing both $T$ and B cell Ir gene defects for these polypeptide antigens [91, 92]. Based on 
these results, Munro and Taussig proposed a two gene model for Ir gene action in which one gene coded for or regulated the production of $\mathrm{T}_{\mathrm{H}} \mathrm{F}$ by $\mathrm{T}$ cells, while another gene coded for or regulated the expression of a $T_{H} F$ acceptor on the $B$ cell [96]. They also demonstrated the ability of anti- $\theta$ treated spleen ("B" cells) to absorb $\mathrm{T}_{\mathrm{H}} \mathrm{F}$, in accord with this hypotheses. Both genes mapped in the I-A subregion for ( $T$, $\mathrm{G})-\mathrm{A}-\mathrm{L}$. The $\mathrm{T}_{\mathrm{H}} \mathrm{F}$ had been shown to be antigen specific by direct binding studies (see above). Munro and Taussig postulated that the acceptor site appeared antigen specific but in fact reflected the inclusion of the tested $\mathrm{T}_{\mathrm{H}} \mathrm{F}$ in a certain "family" of factors using one of the few acceptor molecules possessed by that strain. In their paper, Munro and Taussig reported that the predicted intergeneic complementation between $\left(\mathrm{T}_{\mathrm{H}} \mathrm{F}^{+}\right.$, acceptor $\left.{ }^{-}\right)$and a $\left(\mathrm{T}_{\mathrm{H}} \mathrm{F}^{-}\right.$, acceptor $\left.{ }^{+}\right)$strains existed in the $(\mathrm{B} 10 . \mathrm{BR} \times \mathrm{B} 10 . \mathrm{M}) \mathrm{F}_{1}$, a finding that could not be reproduced, though, by these same workers [97].

At the time the complementation data were first reported, the issue was raised whether the two gene control of immune responses to other antigens, particularly the well studied random terpolymer of glutamic acid-lysine-phenylalanine (GL $\emptyset$ ), might in fact reflect this type of regulation of $\mathrm{T}$ cell help and $\mathrm{B}$ cell triggering. However, experiments clearly showed that both $\alpha$ and $\beta$ genes of the GL $\emptyset$ system needed to be possessed by both the immune $\mathrm{T}$ and the immune $\mathrm{B}$ cell donors for successful antibody production [72], in disagreement with the predictions based on the (T, G)-A - L system. In later studies, Schwartz and coworkers [115] demonstrated the necessity for both the $\alpha$ and $\beta$ GL $\emptyset$ Ir genes in a single cell, the responder macrophage. In light of these data and the recent question concerning the (T, G)-A - L complementation studies, it is difficult to draw any firm conclusions concerning the manner in which Ir gene defects in this system can be complemented for humoral responses in terms of factor production and activity, but this model has served to stimulate extensive work on $\mathrm{T}$ cell derived MHC coded factors.

2. In vitro Sudies on $T_{H} F$ Specific for Synthetic Polypeptides. Howie, Feldmann, and coworkers have also studied soluble helper factors specific for polypeptide antigens, but have carried out these experiments totally in vitro. Spleen cells are cultured in Marbrook-Diener flasks together with low concentrations of antigen (about $1 \mu \mathrm{g} / \mathrm{ml}$ ) for four days, washed, and then recultured in fresh medium, again with $1 \mu \mathrm{g} / \mathrm{ml}$ antigen. The cell-free supernatant is recovered and assessed for activity by addition to another culture containing fresh unprimed spleen cells or B cells plus polypeptide or hapten-polypeptide conjugate as antigen. IgM PFC are assayed four days later and compared to responses in cultures without any $T_{H} F$. Under these conditions, a soluble material is elaborated which specifically augments the PFC response when the antigen (or its haptenated derivative) used for $T_{H} F$ elicitation is in the assay culture $[29,33,52,73]$. This factor comes from $\mathrm{T}$ lymphocytes, and for $(\mathrm{T}, \mathrm{G})-\mathrm{A}-\mathrm{L} \mathrm{T}_{\mathrm{H}} \mathrm{F}$ bears determinants coded for by I region genes, in agreement with data of Taussig et al. Further, this (T, G)-A - $-T_{\mathrm{H}} F$ acts directly on $\mathrm{T}$ depleted spleen cells, as for the in vivo factor. In contrast to the in vivo $(T, G)-A-L T_{H} F$, the in vitro factor binds to ( $T, G)-A-L$ but not (Phe, $G)-A-L$ immunoadsorbents. The reason for this discrepancy, which also applies to the functional activity of the two factors, is unclear at present. This $\mathrm{T}_{\mathrm{H}} \mathrm{F}$ lacks $\mathrm{Ig}$ determinants detected by 
mammalian xenoantisera, but it is bound by chicken anti-mouse Ig antibody immunoadsorbents.

Most intriguing are the data concerning the genetics and mode of action of $(\mathrm{T}$, $\mathrm{G})-\mathrm{A}-\mathrm{L} \mathrm{T}_{\mathrm{H}} \mathrm{F}$ in this in vitro model. Howie and Feldmann [52] find that the production of $(\mathrm{T}, \mathrm{G})-\mathrm{A}-\mathrm{L} \mathrm{T}_{\mathrm{H}} \mathrm{F}$ is under $\mathrm{H}-2$ genetic control and that the haplotypes able to produce this mediator correspond precisely to those reported as $\mathrm{T}_{\mathrm{H}} \mathrm{F}$ producers by Taussig et al. using in vivo methods. These data confirm the hypothesis that at least one site of Ir gene function for $(T, G)-A-L$ is the control of $(T, G)-A-L T_{H} F$ production by $T$ cells. These data do not allow one, however, to determine whether the absence of $T_{H} F$ production by $T$ cells of a given haplotype reflects an inherent $\mathrm{T}$ cell deficit or is the result of Ir gene activity affecting the triggering of $T_{H} F$-producing $T$ cells by macrophages. The data of Singer et al. [118] and Marrack and Kappler [81] on macrophage localized Ir gene defects in (T, G)-A $-\mathrm{L}$ responses support the latter possibility. However, these studies showed $\mathrm{H}-2^{\mathrm{k}}$ macrophages to be deficient, while the $\mathrm{T}_{\mathrm{H}} \mathrm{F}$ data show $\mathrm{H}-2^{\mathrm{k}}$ strains to be factor producers. Taken together, these results may indicate that the observed macrophage defect in $\mathrm{H}-2^{\mathrm{k}}$ mice for $(\mathrm{T}, \mathrm{G})-\mathrm{A}-\mathrm{L}$ responses does not reflect a failure of $\mathrm{T}_{\mathrm{H}}$ activation for $\mathrm{T}_{\mathrm{H}} \mathrm{F}$ production, but rather an inability of these macrophages to mediate a subsequent step in the humoral response.Recently, Howie and Feldmann [53] have reported that this postulated macrophage defect may in fact represent an inability of $\mathrm{H}-2^{\mathrm{k}}$ macrophages to absorb $(\mathrm{T}, \mathrm{G})-\mathrm{A}-\mathrm{L} \mathrm{T}_{\mathrm{H}} \mathrm{F}$ and/or transmit the $\mathrm{T}_{\mathrm{H}} \mathrm{F}$ signal to the $\mathrm{B}$ cell, i. e., the Ir gene defect in $\mathrm{H}-2^{\mathrm{k}}$ mice affects macrophage- $\mathrm{B}$ cell interaction for $\mathrm{T}_{\mathrm{H}} \mathrm{F}$ activity. Clearly, further work is necessary in this area to clarify the actual site of the Ir gene defect and to distinguish between effects on macrophage antigen presentation to $T$ cells versus macrophage presentation of $T$ cell factors to $B$ cells.

\section{B. Helper Factors Enhancing $T$ Dependent $B$ Cell Responses}

Tada and his coworkers $[127,149]$ have reported on the properties of a soluble factor able to enhance in vitro hapten-carrier humoral responses, which differs somewhat from the material described in the preceding sections. This "augmenting" factor increases the magnitude of secondary anti-hapten PFC responses. It is found in cell-free sonicates of $\mathrm{T}$ cells from mice given two injections of soluble carrier protein two weeks apart according to a protocol originally designed to yield potent $\mathrm{T}_{\mathrm{S}}$ responses. In contrast to the $(\mathrm{T}, \mathrm{G})-\mathrm{A}-\mathrm{L} \mathrm{T}_{\mathrm{H}} \mathrm{F}$ this $\mathrm{T}_{\mathrm{a}} \mathrm{F}$ requires carrier primed $\mathrm{T}$ cells for its function, and will not activate $\mathrm{B}$ cells plus antigen alone. Furthermore, this material does not act across allogeneic (I region) barriers, in contrast to (T, G)-A $-L, T_{H} F$. In physiochemical respects, the $T_{a} F$ resembles $T_{H} F$, being 30-60000 in mol. wt., having antigen binding activity, lacking conventional Ig determinants, and bearing I-A subregion coded determinants. These latter specificities may be distinct from those expressed on B cells, since absorption of the anti-I-A alloantisera with B cells prior to conjugation to gel leads to the loss of B cell lytic activity without a reduction in $\mathrm{T}_{\mathrm{a}} \mathrm{F}$ adsorptive capacity. Conversely, adsorption of the anti-I-A antiserum with purified $\mathrm{T}$ cells removes all factor binding activity without decreasing the $B$ cell lytic titer. The source of the $T_{a} F$ is $L y 1^{+}, 23^{-} \mathrm{T}$ cells, in agreement with other studies showing cells of the Ly $1^{+}$lineage to function 
primarily as helpers cells. Further study is necessary to determine the precise relationship between $\mathrm{T}_{\mathrm{a}} \mathrm{F}$ and $\mathrm{T}_{\mathrm{H}} \mathrm{F}$.

\section{Suppressor Factors $\left(\mathbf{T}_{\mathrm{S}} \mathbf{F}\right)$}

\section{A. Studies on Protein Specific $T_{S} F$ Active in Supressing Humoral Responses}

1. In vivo Experiments on $T_{S} F$ from Primed Mice. The earliest studies on soluble $\mathrm{T}$ suppressor factors are those of Tada and colleagues which investigated the role of cell free extracts in the regulation of $\operatorname{IgE}$ antibody production in rats. These experiments showed that $\mathrm{T}_{\mathrm{S}}$-containing thymus and spleen cell populations from rats hyperimmunized to carrier protein yielded a soluble cell free material, following freeze-thaw treatment and centrifugation, which could suppress an ongoing IgE response to the same antigen $[100,124]$. This soluble material bound specifically to the antigen used to prime the $T_{S}$, and lacked conventional immunoglobulin determinants.

More detailed studies on protein specific $T_{S} F$ involved murine responses. Tada and coworkers developed a model in which splenic $T$ cells or thymus cells from mice given two injections of soluble carrier protein [usually keyhole limpet hemocyanin (KLH), bovine gamma globulin (BGG), or egg albumin (EA)], on days 0 and 14, could be shown to be suppressive upon tansfer in vivo on day 28 to syngeneic unprimed recipients challenged with a DNP conjugate of the same carrier protein [130]. This suppressor cell effect, which decreased high affinity IgG responses preferentially compared to $\operatorname{IgM}$ or low affinity $\operatorname{IgG}$, could also be mediated by a cell free extract prepared from the same cell population by sonication, then centrifugation [125].

The in vivo studies [131] revealed that the $\mathrm{T}_{\mathrm{S}} \mathrm{F}$ was antigen specific in its action, failing to suppress DNP-BGG responses when prepared from KLH primed cells and vice versa. Furthermore, addition of the appropriate carrier antigen KLH to $\mathrm{KLH}-\mathrm{T}_{\mathrm{S}} \mathrm{F}$, together with DNP-BGG as challenge antigen, also failed to cause suppression of the DNP response in vivo, suggesting that antigen plus $T_{S} F$ did not generate an antigen nonspecific suppressor signal (but see below on in vitro studies). Finally, the $\mathrm{T}_{\mathrm{S}} \mathrm{F}$ could be specifically adsorbed by antigen-conjugated Sepharose beads.

Further in vivo studies revealed that the $\mathrm{T}_{\mathrm{S}} \mathrm{F}$ was not bound to immunoadsorbents specific for a variety of immunoglobulin determinants, and gel filtration suggested a size for $\mathrm{T}_{\mathrm{S}} \mathrm{F}$ of 40-60000 daltons. Also, the factor could be adsorbed on columns made from alloantisera specific for the $\mathrm{H}-2$ region of the $\mathrm{T}_{\mathrm{S}} \mathrm{F}$ donor. In addition to this evidence for $\mathrm{H}-2$ coded determinants on the $\mathrm{T}_{\mathrm{S}} \mathrm{F}$ itself, it was found that the suppressive activity of a given $\mathrm{T}_{\mathrm{S}} \mathrm{F}$ was seen only when the factor was tested in the syngeneic or an $\mathrm{H}-2$ compatible strain. Thus, BALB/c $\left(\mathrm{H}-2^{\mathrm{d}}\right) \mathrm{KLH}-\mathrm{T}_{\mathrm{S}} \mathrm{F}$ worked in BALB/c and DBA/2 (H-2 $\left.{ }^{d}\right)$ mice, but not in C57BL/6 $\left(\mathrm{H}-2^{\mathrm{b}}\right)$ mice, although $\mathrm{C} 57 \mathrm{BL} / 6 \mathrm{KLH}-\mathrm{T}_{\mathrm{S}} \mathrm{F}$ was active in syngeneic animals. These data were the first to indicate that the activity of soluble $T$ cell factors might be restricted by the same genetic region $(\mathrm{H}-2)$ containing the genes that coded for the determinants they carry [131]. 
2. In Vitro Studies on $T_{S} F$ from Primed Mice. Further characterization of the nature and mode of action of protein-specific $\mathrm{T}_{\mathrm{S}} \mathrm{F}$ was carried out in vitro using secondary DNP PFC responses in Marbrook cultures to DNP-protein conjugates. The spleen cells were obtained from mice primed one month previously with the relevant hapten-carrier conjugate and pertussis adjuvant. Under these conditions, it is the $\mathrm{IgG}$ response which is predominantly suppressed by the $T_{S} F$. Early experiments confirmed the results obtained in vivo, and provided several new findings [133]: (1) The $\mathrm{T}_{\mathrm{S}} \mathrm{F}$ could not be recovered from the supernatant of cultures of KLH $\mathrm{T}_{\mathrm{S}}$ and $\mathrm{KLH}$, but was still present in the sonicates of such $\mathrm{T}_{\mathrm{S}}$ after the culture period. This is different from the results with the $\mathrm{T}_{\mathrm{H}} \mathrm{F}$ described by Taussig [139], which could be released from in vivo primed cells during in vitro culture. It also differs from the data of several other groups on both $\mathrm{T}_{\mathrm{H}} \mathrm{F}$ (see above) and $\mathrm{T}_{\mathrm{S}} \mathrm{F}$ (see below). (2) The $\mathrm{T}_{\mathrm{S}} \mathrm{F}$ acted on $T$ cells, not $B$ cells. This was shown by adding either $E A-T_{S} F$ or $K L H-T_{S} F$ to DNP-EA primed spleen cells together with DNP-EA and DNP-KLH. DNP-B cells should bind both DNP compounds, permitting either or both $\mathrm{T}_{\mathrm{S}} \mathrm{F}$ materials to affect these cells. However, under such conditions, only the EA-T $\mathrm{F}$ able to act on the primed $E A T_{H}$ showed significant suppressor function. (3) The H-2 determinants present on the $T_{S} F$ were coded for by a "new" I subregion termed I-J [126], first defined at that time by Murphy et al. [98].

The experiments demonstrating the importance of this new subregion were based on the fact that $\mathrm{KLH} \mathrm{T} \mathrm{T}_{\mathrm{S}} \mathrm{F}$ failed to act across $\mathrm{H}-2$ barriers. By studying a series of congenic mice with recombinant I regions, it was possible to map the location of the genes controlling this restriction. One of the critical tests involved B10.A(5R) mice as factor donors. The data showed that $5 \mathrm{R} K \mathrm{KLH}_{-} \mathrm{T}_{\mathrm{S}} \mathrm{F}$ was not suppressive for $\mathrm{C} 57 \mathrm{BL} / 6$ or $\mathrm{BALB} / \mathrm{c}$ mice, although $\mathrm{H}-2$ maps available at that time designated the $5 \mathrm{R}$ I region as a recombinant containing solely $\mathrm{H}-2^{\mathrm{b}}$ and $\mathrm{H}-2^{\mathrm{d}}$ genes, and at least one of these assay strains should have possessed the appropriate I region target for the $\mathrm{T}_{\mathrm{S}} \mathrm{F}$. Conversely, the same $5 \mathrm{R} \mathrm{T}_{\mathrm{S}} \mathrm{F}$ did suppress $\mathrm{CBA}\left(\mathrm{H}-2^{\mathrm{k}}\right)$ responses, although this would seem to violate the $\mathrm{H}-2$ restriction rule. Because the $5 \mathrm{R} \mathrm{H}-2$ derives from a $(b \times a)$ recombination, and (a) itself is considered a natural $(k \times d)$ recombinant, one possible interpretation of the above data was that the $5 \mathrm{R} I$ region included an $\mathrm{I}^{\mathrm{k}}$ derived gene located between I-B and I-E/C which was the crucial genetic region for $T_{S} F$ function. This putative new subregion, termed I-J, was also consistent with the data on antisera absorption of $T_{S} F$. B10.A(3R) anti-5R antiserum should have had no anti-Ia activity according to then current data, yet this antiserum did adsorb the KLH- $\mathrm{T}_{S} \mathrm{~F}$. Tests of a panel of other sera showed that in all cases, the adsorption of KLH- $\mathrm{T}_{\mathrm{S}} \mathrm{F}$ correlated with the postulated I-J subregion intercalated between I-B and I-E/C. As will be discussed later, most other antigenspecific $T_{S} F$ have also been found to bear I-J coded determinants.

The relevant determinants coded for on $T_{S} F$ by the I-J subregion are not expressed in detectable quantity on B lymphocytes, since large numbers of these cells cannot adsorb the $T_{S} F$ binding activity from anti-I-J sera. Small numbers of $T$ cells, however, efficiently adsorb the anti- $T_{S} F$ antibody [123]. Recently, the presence of I-J determinants on $T_{S}$ has been shown by direct cytotoxicity tests on $T_{S}$ enriched by antigen binding procedures $[101,135]$, as well as on a $\mathrm{Ly} 1^{+} \mathrm{T}_{\mathrm{H}}$ subclass adherent to nylon wool [128]. Adsorption of anti-I-J sera with these distinct $\mathrm{I}_{-} \mathrm{J}^{+}$ cell types indicates a minimum of two distinct I-J determinants distinguishing the 
two $T$ cell subsets, and antibodies to these determinants are present in varying proportion in different anti-I-J sera, complicating the use of such reagents in studies on immunoregulatory $\mathrm{T}$ cells. Anti-I-J antisera can also block the action of $\mathrm{T}_{\mathrm{S}} \mathrm{F}$ [123].

Treatment of $T_{S}$ with anti-Ly 1 serum plus complement $(C)$, followed by removal of dead cells and debris, left a population of cells that still yielded $\mathrm{T}_{\mathrm{S}} \mathrm{F}$ upon sonication. Similar treatment with anti-Ly 2 serum $+\mathrm{C}$ removed the cells containing the $T_{S} F$. Thus, $T_{S} F$ producing cells, at the time $T_{S} F$ is extracted, are Ly $1^{-}, 2^{+}$. Whole spleen cells but not anti-Thy $1.2+\mathrm{C}$ treated spleen cells of the same $\mathrm{H}-2$ haplotype as the $\mathrm{T}_{\mathrm{S}} \mathrm{F}$ donor could adsorb the $\mathrm{T}_{\mathrm{S}} \mathrm{F}$ activity from a sonicate; however, attempts to adsorb $\mathrm{T}_{\mathrm{S}} \mathrm{F}$ with nylon purified $\mathrm{T}$ cells were unsuccessful. The nylon adherent cells proved able to bind $T_{S} F$, indicating that the target of $T_{S} F$ was a nylon adherent $T$ cell. This cell was then studied. DNP-primed B cells plus nylon purified KLH T cells were cultured with or without added nylon adherent cells, in the presence or absence of $\mathrm{KLH}-\mathrm{T}_{\mathrm{S}} \mathrm{F}$. Only when the nylon adherent $\mathrm{T}$ cells were present did the $T_{S} F$ suppress the PFC response to DNP-KLH. Treatment of the nylon adherent cells with either anti-Ly 1 or anti-Ly $2+\mathrm{C}$ removed their activity, and since $\mathrm{Ly} 1^{+}+\mathrm{Ly} 2^{+}$cells added together did not reconstitute suppressor function, it appears that the $\mathrm{T}_{\mathrm{S}} \mathrm{F}$ target is an Ly $123^{+}$cell. Furthermore, these $\mathrm{Ly}$ $123^{+}$cells must come from mice primed with the same antigen as the $\mathrm{T}_{\mathrm{S}} \mathrm{F}$ donors and must be I-J compatible with the $T_{S} F$ for it to act. It is the uptake of $T_{S} F$ by these Ly $123^{+}$antigen activated cells that is blocked by anti-I-J antiserum. The effect of $\mathrm{T}_{\mathrm{S}} \mathrm{F}$ on the Ly $123^{+}$cell appears to be a triggering of this cell, in the presence of antigen, to either differentiation into an active Ly $2,3^{+} \mathrm{T}_{\mathrm{S}}$ or to aid an Ly $2,3^{+}$cell to become an active $T_{S}$, i.e., the $T_{S} F$ induces suppressor $T$ cells. Finally, the suppressor cell induced by $\mathrm{T}_{\mathrm{S}} \mathrm{F}$ plus antigen via the Ly $123^{+}$cell can suppress in an antigen nonspecific manner, and, apparently, act across I-J (H-2) barriers. The target of this induced suppressor cell appears to be an Lyt $1^{+}, \mathrm{I}^{-} \mathrm{J}^{-}$carrier-specific $\mathrm{T}_{\mathrm{H}}$ cell. Recently, it has been found that the same KLH-T $\mathrm{F}$ extract, though not necessarily the same suppressor molecule, can have a direct suppressive effect on a different Lyt1 ${ }^{+} \mathrm{T}_{\mathrm{H}}$, which bears I-J subregion coded determinants [129].

In additition, Taniguchi et al. have derived $\mathrm{T}$ cell hybridomas from KLH antigen binding $T_{S}$ from $B 6$ mice [138] which produce $K L H-T_{S} F$. Investigation of the nature of this material has revealed it to be virtually identical to the $T$ cell extracts, i.e., about 60000 daltons in mol. wt. and bearing I-J subregion coded determinants. It also reacts with an anti- $\mathrm{V}_{\mathrm{H}}$, but not anti- $\mathrm{V}_{\mathrm{K}}$ or $\mathrm{V}_{\lambda}$ antiserum specific for framework determinants on these chains [102]. Finally, the I-J determinants and antigen combining site seem to be on distinct noncovalently linked chains, since the filtrates of an anti-I-J ${ }^{b}$ column and of a KLH column, each loaded with the hybridoma KLH-T $\mathrm{T}_{\mathrm{S}} \mathrm{F}$ and each devoid of suppressive activity by itself, can, when combined, show potent suppression [132].

\section{Other $T_{S} F$ Specific for Carrier Proteins in Humoral Responses. Several other $\mathrm{T}_{\mathrm{S}} \mathrm{F}$} specific for conventional protein antigens and active on humoral immune responses have been reported. One system involves $T_{S} F$ derived from $T_{S}$ specific for human gamma globulin $(\mathrm{H} \gamma \mathrm{G})$. These $\mathrm{T}_{\mathrm{S}}$ are induced using deaggregated protein to tolerize the recipient and induce $T_{S}[6,60,135]$. Such $T_{S}$ have been characterized as Ly $2^{+}, I-$ 
$\mathrm{J}$ cells [135], and yield, upon disruption or by secretion, a $\mathrm{T}_{\mathrm{S}} \mathrm{F}$ which is strikingly similar to the $\mathrm{KLH}-\mathrm{T}_{\mathrm{S}} \mathrm{F}$ detailed above $[18,136,137]$. The $\mathrm{HyG} \mathrm{T}_{\mathrm{S}} \mathrm{F}$ is $40-50000$ daltons, nonimmunoglobulin, antigen-binding, and bears I region coded determinants. No data is available on the activity of this material in H-2 (I-J) incompatible animals, nor on the ability of $\mathrm{H} \gamma \mathrm{G} \mathrm{T}_{\mathrm{S}} \mathrm{F}$ to induce $\mathrm{T}_{\mathrm{S}}$.

The other major experimental system for studying $\mathrm{T}_{\mathrm{S}} \mathrm{F}$ to protein antigens has been reported by Kontiainen and coworkers. This model makes use of the in vitro humoral response system employed by Feldmann [31,34]. Spleen cells are cultured for four days in the presence of high concentrations $(100 \mu \mathrm{g} / \mathrm{ml})$ of antigen $(\mathrm{KLH})$, washed, and recultured with a low concentration $(1 \mu \mathrm{g} / \mathrm{ml})$ of antigen to permit $T_{S} F$ secretion. Under these conditions, a soluble supernatant material is released by cells via an energy-requiring process, which can suppress DNP-PFC responses to the same carrier antigen as that used for $\mathrm{T}_{\mathrm{S}} \mathrm{F}$ production [75]. This suppression occurs using either in vitro or in vivo primed $\mathrm{T}_{\mathrm{H}}$, which are needed for $\mathrm{PFC}$ responses in these cultures. No $\mathrm{H}-2$ restrictions on the action of this $\mathrm{T}_{\mathrm{S}} \mathrm{F}$ have been observed to date. Nonetheless, this $T_{S} F$ closely resembles in physiochemical terms the Tadatype $T_{\mathrm{S}} \mathrm{F}$ it is about 50000 daltons in mol. wt., has specific antigen binding activity, bears I region coded determinants, lacks Ig determinants recognized by mammalian antisera, and is a protein. This $T_{S} F$ also differs from the inducing $T_{S} F$ in that its target is an $\mathrm{Ly} 1^{+} 2^{-} \mathrm{T}_{\mathrm{H}}$ cell, not an Ly $123^{+}$cell, and no evidence exists to indicate that it is capable of inducing Ly $2^{+} \mathrm{T}_{\mathrm{S}}$ [76]. Thus, despite a close physical resemblance, there are at least two distinct $T_{\mathrm{S}} \mathrm{F}$ molecules coded for by same I subregion, each with a distinct functional activity. Hybridomas producing this in vitro type of $\mathrm{KLH}-\mathrm{T}_{\mathrm{S}} \mathrm{F}$ have been reported [77].

\section{B. Studies on $T_{S} F$ Specific for Polypeptides Antigens Under Ir Gene Control}

1. General Features of the GAT/GT Models. The use of antigens, the response to which is under Ir gene control, has aided in dissecting the suppressor $\mathrm{T}$ cell pathways and the role of $T_{S} F$ in suppressor cell activity. The best studied of these antigens are the random polypeptides L-glutamic acid ${ }^{60}$-L-alanine ${ }^{30}-\mathrm{L}_{-}$-tyrosine ${ }^{10}$ (GAT) and L-glutamic acid ${ }^{50}$-L-tyrosine ${ }^{50}$ (GT). GAT responses are under dominant H-2 linked Ir gene control mapping to the I-A subregion [24]. The nonresponder haplotypes are $\mathrm{H}-2^{\mathrm{p}, \mathrm{q}, \mathrm{s}}$. Mice bearing these haplotypes fail to give either humoral or cell mediated immune responses to GAT, but will respond with anti-GAT antibody when administered GAT electrostatically complexed with the carrier methylated bovine serum albumin (GAT-MBSA). GAT and GAT-MBSA primary in vitro responses are characterized by IgG $\mathrm{PFC}$ under the usual conditions of assay [67].

Gershon et al. [44] first proposed that GAT nonresponder mice did show in vivo lymphoid responsiveness to GAT administration and suggested the possibility that this reflected $\mathrm{T}_{\mathrm{S}}$ activation. A series of studies by Kapp and Benacerraf documented in detail the occurrence and $\mathrm{T}$ cell nature of the suppressor cells induced in nonresponder mice by GAT. The standard assay for these $\mathrm{T}_{\mathrm{S}}$ became their ability to decrease PFC responses to GAT-MBSA in vivo or in vitro $[7,9,68]$. Very recently, the ability of GAT- $T_{S}$ to suppress nonresponder $T$ cell proliferative responses to GAT after GAT-MBSA priming has also been used for studying suppression in this 
model [66]. Similar experiments were carried out using GT. This antigen does not lead to responses in any tested inbred mouse strain, although it is immunogenic in an outbred line. The inbred strains can be divided into two broad groups, however, those whose GT-MBSA responses are suppressed by prior GT administration $\left(\mathrm{H}-2^{\mathrm{d}, \mathrm{k}, \mathrm{s}}\right)$, and those whose responses are not suppressed by such treatment $\left(\mathrm{H}-2^{\mathrm{a}, \mathrm{b}, \mathrm{q}}\right)$ $[20,21]$. The work of Tada et al. [131] led to attempts to produce GAT and GT-T $\mathrm{S} F$ by sonication of spleen and thymus cells containing active $T_{\mathrm{S}}$. Such extracts did suppress GAT-MBSA or GT-MBSA responses of syngeneic mice, and were also active in vitro, permitting easy assay $[69,70,147,150]$. These polypeptide specific $\mathrm{T}_{\mathrm{S}} \mathrm{F}$ were subjected to a similar immunochemical and functional analysis to that employed previously for ( $\mathrm{T}, \mathrm{G})-\mathrm{A}-\mathrm{L} \mathrm{T}_{\mathrm{H}} \mathrm{F}$ and simultaneously by Tada for $\mathrm{KLH}$ $\mathrm{T}_{\mathrm{S}} \mathrm{F}$. The results showed that in many respects $\mathrm{GAT}_{\mathrm{S}} \mathrm{T}_{\mathrm{S}} \mathrm{F}$ and $\mathrm{GT}-\mathrm{T}_{\mathrm{S}} \mathrm{F}$ are similar to KLH-T $\mathrm{S}_{\mathrm{S}} \mathrm{F}$ (1) They are proteins of 40-50000 mol. wt.; (2) They bear I region, more specifically, I-J, coded determinants; (3) they have antigen binding specificity, and can, in fact, discriminate between the two closely related polypeptides; and (4) they lack constant region immunoglobulin determinants $[145,146]$. In contrast to KLH- $\mathrm{T}_{\mathrm{S}} \mathrm{F}$ of the Tada type, GAT- $\mathrm{T}_{\mathrm{S}} \mathrm{F}$ is associated with some serologically active antigen. This was demonstrated by showing that GAT- $T_{S} \mathrm{~F}$ activity bound to a rabbit anti-GAT immunoadsorbent. This binding was not seen when the GAT-T ${ }_{5} F$ had first been purified by passage over insolubilized GAT bound to Sepharose, indicating that this fragment of antigen was lost during the purification process [145]. The functional importance of this antigen fragment will be discussed below.

2. $T_{S} F$ Stimulates $T_{S_{2}}$. These polypeptide specific $\mathrm{T}_{\mathrm{S}} \mathrm{F}$ differ from the $\mathrm{T}_{\mathrm{S}} \mathrm{F}$ described by Tada in that they act very efficiently across all allogeneic, including $\mathrm{H}-2$, barriers. Thus $\mathrm{H}-2^{\mathrm{q}} \mathrm{GAT}-\mathrm{T}_{\mathrm{S}} \mathrm{F}$ acts on $\mathrm{H}-2^{\mathrm{s}}$ target spleen cells with the same activity it shows on syngeneic $\mathrm{H}-2^{\mathrm{q}}$ cells [65]. Similar data was obtained for GT-T $\mathrm{F}$ in the same genetic combinations $\left(\mathrm{H}-2^{\mathrm{d}}, \mathrm{H}-2^{\mathrm{k}}\right)$ showing strict $\mathrm{I}-\mathrm{J}$ restrictions for $\mathrm{KLH}-\mathrm{T}_{\mathrm{S}} \mathrm{F}$ [150]. This lack of requirement for I-J homology between $T_{S} F$ and target cell is not due to a difference in the apparent mode of action of these factors, however. Thus, the I-J restriction for KLH-T $\mathrm{K}$ applies to its ability to induce $\mathrm{Ly} 123^{+} \mathrm{T}$ cells to generate active Ly $23^{+} \mathrm{T}_{\mathrm{S}}$ [123]. As noted above, the KLH-T $\mathrm{F}$ studied by Kontiainen which shows no I-J restriction acts directly on $L y 1^{+} T_{H}$ without $T_{S}$ induction [76]. Waltenbaugh et al. [151, 152] first demonstrated the ability of polypeptide specific $\mathrm{T}_{\mathrm{S}} \mathrm{F}$ to induce $\mathrm{T}_{\mathrm{S}}$ (termed $\mathrm{T}_{\mathrm{S}_{2}}$ ). They found that in vivo administration of either $\mathrm{GT}-\mathrm{T}_{\mathrm{S}} \mathrm{F}$ or $\mathrm{GAT}-\mathrm{T}_{\mathrm{S}} \mathrm{F}$ gave rise within seven days to active suppressor T cells in the spleens of treated mice. In contrast to the KLH system, the target $T$ cells did not need to be antigen primed, nor did exogeneous antigen need to be added to the $T_{S} F$ for induction to occur. Further, this induction of $T_{S_{2}}$ occured across I-J barriers, since BALB/c $\left(H-2^{d}, I-J^{d}\right) G T-T_{S} F$ was active in producing $T_{\mathrm{S}_{2}}$ in A/J $\left(\mathrm{H}-2^{\mathrm{a}}, \mathrm{I}-\mathrm{J}^{\mathrm{k}}\right)$ mice.

This induction pathway has been studied in detail in this laboratory. Early experiments demonstrated that $\mathrm{T}_{\mathrm{S}_{2}}$ induction could occur in as short a time as two days under in vitro conditions [39]. These $T_{\mathrm{S}_{2}}$ were fully active either in vivo or in vitro in syngeneic mice. If GAT- $\mathrm{T}_{\mathrm{S}} \mathrm{F}$ purified over GAT-immunoadsorbents was used for $\mathrm{T}_{\mathrm{S}_{2}}$ induction instead of the crude extract, no active suppressors appeared. This purified material, which was known to lack the fragment of GAT usually 
associated with crude GAT- $\mathrm{T}_{\mathrm{S}} \mathrm{F}$, was nonetheless fully active when used to directly suppress GAT-MBSA responses in culture. These data suggested a cruical role for antigen in $T_{\mathrm{S}_{2}}$ induction. Addition of nonsuppressive (nanogram) amounts of GAT to the purified GAT- $T_{S} F$ leads to efficient $T_{S_{2}}$ induction. Thus, although not revealed by the initial in vivo experiments, GAT- $T_{S} F$ shares with KLH-T $F$ a requirement for both an $I$ region coded product and antigen for $\mathrm{T}_{\mathrm{S}_{2}}$ triggering.

3. Ir Gene Status and $T_{S_{2}}$ Induction. The presence of genetic restrictions for $T_{S} F$ induction of $T_{\mathrm{S}_{2}}$ F induction of $\mathrm{T}_{\mathrm{S}_{2}}$ was restudied in both the GAT and GT models in vitro. In both cases, $\mathrm{T}_{\mathrm{S}} \mathrm{F}$ efficiently activated $\mathrm{T}_{\mathrm{S}_{2}}$ using allogeneic, I-J incompatible spleen cells ([40] and unpublished observations). Experiments also looked at the existence of Ir gene barriers to GAT-T $\mathrm{F}$ activity. Early work showed that GAT$\mathrm{T}_{\mathrm{S}} \mathrm{F}$, while active in all nonresponder strains, did not suppress responder mice or (responder $\times$ nonresponder) $\mathrm{F}_{1}$ mice, even when GAT-MBSA rather than GAT was used as antigen [70]. This raised the question as to whether in this system, I-A coded Ir genes, as opposed to I-J subregion genes, restricted GAT- $\mathrm{T}_{\mathrm{S}} \mathrm{F}$ activity. However, both in vivo and in vitro studies ruled out this interpretation [41]. Administration of $\mathrm{GAT}-\mathrm{T}_{\mathrm{S}} \mathrm{F}$ in vivo to responder mice one week prior to antigen challenge suppressed subsequent GAT PFC responses. This indicated that nonresponder derived GAT- $\mathrm{T}_{\mathrm{S}} \mathrm{F}$ could work in responder mice, presumably by inducing $\mathrm{T}_{\mathrm{S}_{2}}$. This was also directly demonstrated in vitro. Responder (BALB/c-H-2 $2^{d}$ ) spleen cells were incubated in DBA/1 $\left(\mathrm{H}-2^{\mathrm{q}}\right)$ GAT-T $\mathrm{S}$ for two days, washed, and transferred into $\mathrm{BALB} / \mathrm{c}$ mice, or BALB/c spleen cell cultures. Such $\mathrm{GAT}-\mathrm{T}_{\mathrm{S}} \mathrm{F}$ cultured responder cells significantly reduced GAT PFC responses. The active cells were sensitive to anti-Thy $1.2+\mathrm{C}$, indicating they were $\mathrm{T}$ cells. Thus, Ir genes do not restrict $\mathrm{T}_{\mathrm{S}} \mathrm{F}$ activity for $\mathrm{T}_{\mathrm{S}_{2}}$ induction. These experiments do not rule out, Ir gene mediated restrictions on $T_{S} F$ action at other sites.

These findings in the GAT and GT models have been used to provide information on the target of $\mathrm{T}_{\mathrm{S}} \mathrm{F}$ action and genes controlling both $\mathrm{T}_{\mathrm{S}} \mathrm{F}$ production and $\mathrm{T}_{\mathrm{S}_{2}}$ activity. Because GT-T $\mathrm{T}_{\mathrm{S}} \mathrm{F}$ acts across I-J barriers, it was possible to ask if induced $T_{\mathrm{S}_{2}}$ bear I-J determinants and if, in fact, these determinants are passively acquired or actively produced. This was accomplished by treating $A / J\left(I-J^{k}\right) T_{S_{2}}$ induced using $\mathrm{BALB} / \mathrm{c}\left(\mathrm{I}-\mathrm{J}^{\mathrm{d}}\right) \mathrm{GT}-\mathrm{T}_{\mathrm{S}} \mathrm{F}$ with an anti-I- $\mathrm{J}^{\mathrm{k}}$ antiserum prepared so as not to crossreact with $I-J^{d}$ determinants $[(B 10 . A(3 R) \times D B A / 2$ anti-B10.A $(5 R)]$. The elimination of $\mathrm{A} / \mathrm{J} G \mathrm{GT}-\mathrm{T}_{\mathrm{S}_{2}}$ function by treatment with this antiserum $+\mathrm{C}$ indicated that $\mathrm{T}_{\mathrm{S}_{2}}$ are $\mathrm{I}-\mathrm{J}^{+}$and that these $\mathrm{I}-\mathrm{J}$ determinants are derived actively from the $\mathrm{T}_{\mathrm{S}_{2}}$ precursor itself [40].

4. Ly Phenotype. Experiments conducted in collaboration with Dr. Harvey Cantor have provided preliminary evidence that the precursor of the $T_{\mathrm{S}_{2}}$ has the same Ly phenotype as the KLH- $\mathrm{T}_{\mathrm{S}} \mathrm{F}$ nylon wool adherent target cell. (B6D1)F $\mathrm{F}_{1}$ spleen cells were treated with anti-Ly 1 , anti-Ly 2 , or NMS + C and cultured in vitro with GAT$\mathrm{T}_{\mathrm{S}} \mathrm{F}$ for two or three days. Other cells were similarly cultured without pretreatment, then exposed to anti-Ly antisera plus $\mathrm{C}$ after $\mathrm{T}_{\mathrm{S}_{2}}$ induction. These various cell types were then titrated into fresh cultures of syngeneic spleen cells stimulated with GAT. Pretreatment with either anti-Ly 1 or anti-Ly $2+\mathrm{C}$ prevented $\mathrm{T}_{\mathrm{S}_{2}}$ induction and cultures containing Ly $1^{+}$and Ly $2^{+}$cells mixed together did not show a reconstitution of $\mathrm{T}_{\mathrm{S}_{2}}$ induction. These data indicate an $\mathrm{Ly} 123^{+}$cell is involved in $\mathrm{T}_{\mathrm{S}_{2}}$ 
generation. The treatment of already induced $\mathrm{T}_{\mathrm{S}_{2}}$ showed that only anti-Ly $2+\mathrm{C}$, or anti-I- $\mathrm{J}+\mathrm{C}$, but not anti-Ly $1+\mathrm{C}$, eliminated $\mathrm{T}_{\mathrm{S}_{2}}$ mediated suppression. Thus, the mature $\mathrm{T}_{\mathrm{S}_{2}}$ is Ly $1^{-}, 2^{+}, \mathrm{I}_{-} \mathrm{J}^{+}$. Whether this indicates a change in differentiation antigens from Ly $123^{+}$to Ly $23^{+}$by a single cell type, or whether Ly $123^{+}$cells are required for $\mathrm{T}_{\mathrm{S}} \mathrm{F}$ to trigger $\mathrm{Ly} 23^{+}$cells is not yet known. At this point, these data are in full agreement with those of Tada [123], apart from the I-J restriction phenomenon.

5. MHC Control of $T_{S} F$ Production and $T_{S_{2}}$ Induction. We have also looked at the role of $\mathrm{H}-2$ linked genes in the regulation of $\mathrm{T}_{\mathrm{S}} \mathrm{F}$ production and $\mathrm{T}_{\mathrm{S}_{2}}$ induction. Prior investigations revealed that suppression to GT was under the control of complementing genes (termed immune suppression or Is genes) located in the I-A and I-C subregions $[8,22]$. Thus two genes, in additition to I-J, are involved in GT specific suppression. Waltenbaugh et al. had demonstrated that $\mathrm{A} / \mathrm{J}$ mice (non-suppressor animals) fail to produce detectable GT- $T_{S} F$, but nevertheless could be suppressed by active $G T-T_{S} F$, at least in part due to $T_{S_{2}}$ induction [152]. Since $F_{1}$ mice between $\mathrm{A} / \mathrm{J}$ and another nonsuppressor strain, B6, led to complementation for the full suppressor pathway, it was postulated that the B6 might provide the ability to produce $\mathrm{GT}-\mathrm{T}_{\mathrm{S}} \mathrm{F}$ which in turn would act due to the ability of the $\mathrm{A} / \mathrm{J}$ genome to yield $\mathrm{T}_{\mathrm{S}_{2}}$. This hypothesis was tested by preparing putative $\mathrm{B} 6 \mathrm{GT}-\mathrm{T}_{\mathrm{S}} \mathrm{F}$ and assaying this extract for function both directly and for $\mathrm{T}_{\mathrm{S}_{2}}$ induction in $\mathrm{B} 6$, and other strains of mice. B6 mice do produce GT- $\mathrm{T}_{\mathrm{S}} \mathrm{F}$, which fails to act in $\mathrm{B} 6$ itself, but which directly suppresses $A / J,(B 6 A) F_{1}$, and other strains, and yields $T_{S_{2}}$ as well. Thus, it appears that $A / J$ mice fail to make $G T-T_{S} F$, but respond to active factor with $T_{S_{2}}$ activity, while $\mathrm{B} 6$ mice produce $\mathrm{T}_{\mathrm{S}} \mathrm{F}$, but cannot yield $\mathrm{T}_{\mathrm{S}_{2}}$ able to suppress syngeneically. These results are reminiscent of the $T_{H} F$ studies on $(T, G)-A-L T_{H} F$, except that they involve two $T$ cell functions, instead of $T$ and $B$ cells. Similar findings were also reported for $\mathrm{KLH}-\mathrm{T}_{\mathrm{S}} \mathrm{F}$ [134]. In this case, $\mathrm{A} / \mathrm{J}$ also failed to produce $\mathrm{T}_{\mathrm{S}} \mathrm{F}$ and all $\mathrm{B} 10$ background mice failed to respond to the factor. Two crucial observations in these latter studies were that the genes controlling these effects were not $\mathrm{H}-2$ linked and that it was the B10, not the B6 background, that possessed the defect. Because of these findings the GT model was examined for $\mathrm{H}-2$ control of $T_{S} F$ production and activity. In contrast to the situation for KLH-T $F$, changing the $\mathrm{H}-2$ type of the animals changes the defect in the GT- $T_{S}$ pathway. Most telling are the experiments with $\mathrm{B} 10$ and $\mathrm{B} 10$.A recipients of $\mathrm{GT}-\mathrm{T}_{\mathrm{S}} \mathrm{F} . \mathrm{B} 10(\mathrm{H}-$ $\left.2^{b}\right)$ spleen cells are not suppressed by either B6 or A.BY $\left(\mathrm{H}-2^{b}\right) \mathrm{GT}-\mathrm{T}_{\mathrm{S}} \mathrm{F}$, while B10.A $\left(\mathrm{H}-2^{\mathrm{a}}\right)$ cells are. Conversely, B10.A mice, in contrast to B6 mice, fail to yield active GT-T $T_{S} F$, while A.BY $\left(H-2^{b}\right)$ mice, congeneic with A strain, now generate $G T-T_{S} F$ in response to $\mathrm{GT}$ challenge. Furthermore, the defect in $\mathrm{B} 6$ mice is antigen specific, in that GAT- $\mathrm{T}_{\mathrm{S}} \mathrm{F}$ can induce GAT specific $\mathrm{T}_{\mathrm{S}_{2}}$ under conditions identical to those in which $G T-T_{S} F$ fails to give GT- $T_{S}$. One striking possibility raised by these data is that activation of $T_{S_{1}}$ by $G T$ requires antigen presentation by cells possessing a surface Ia structure produced by interaction of I-A and I-C Is gene products, in analogy with $I-A_{\beta}: I-E_{\alpha}$ generation of macrophage Ia for "presentation" of the terpolymer glutamic acid-lysine-phenylalanine $[19,115]$. Failure of $T_{S} F$ to act might also involve similar defects in presentation by Ia molecules, perhaps in this case of the idiotypic determinants of the $\mathrm{T}_{\mathrm{S}} \mathrm{F}$ combining site [43, 122 and see below]. 
6. Idiotypic Analysis of $T_{S} F$. The possible presence of shared idiotypic determinants on GAT specific antibodies and GAT-T $\mathrm{S}_{\mathrm{S}} \mathrm{F}$ has also been examined. A common (cross-reactive) idiotype exists on the majority of anti-GAT antibodies of all studied inbred strains of mice [61-64]. This idiotype, termed CGAT, is also found on antiGAT antibodies of certain rat strains [62] and may be present in guinea pigs [148] as well. It is associated with binding specificity for GAT or GT-type determinants, being found also in sera to GLT, (T, G)-A - L, and GT, but absent from anti-Lglutamic acid $^{60}$-L-alanine ${ }^{40}(\mathrm{GA})$ sera. Because of its broad representation in mice (and other species) this idiotype is an excellent candidate for a marker for a germ line $\mathrm{V}_{\mathrm{H}}$ gene, and as such, was thought likely to occur also on $\mathrm{GAT}-\mathrm{T}_{\mathrm{S}} \mathrm{F}$ if such $\mathrm{T}$ cell derived material made use of the $\mathrm{Ig} \mathrm{V}_{\mathrm{H}}$ gene pool for its antigen combining site.

Anti-CGAT antiserum was raised in guinea pigs using as immunogen anti-GAT affinity purified D1.LP $\left(\mathrm{H}-2^{b}\right)$ antibodies which had been passed through an anti-H$2^{\mathrm{b}}$ immunoadsorbent column to remove any $\mathrm{MHC}$ coded $\mathrm{T}$ cell products which might have copurified with the antibodies. This anti-CGAT or control guinea pig serum was coupled to Sepharose and DBA/1 and SJL nonresponder GAT-T $\mathrm{S}$ passed over the gel. The filtrates of these columns, as well as the acid eluates, were tested for both suppressive activity on nonresponder spleen cells and for $T_{\mathrm{S}_{2}}$ induction using responder cells [42].

Such anti-CGAT immunoadsorbents totally remove the suppressive activity of purified GAT- $T_{S} F$ preparations, and the active GAT- $T_{S} F$ can be recovered in the acid eluate. Furthermore, the eluted $T_{S} F$ still bears I-J determinants. As a control, it was shown that GA-T $T_{S} F$ did not detectably bind to anti-CGAT adsorbents, in accord with the absence of CGAT determinants on anti-GA antibodies. These data provide presumptive evidence of sharing of $V_{H}$ structures on antibodies and I region coded $\mathrm{T}$ cell products. The possibility that these idiotypic structures may play a direct role in $\mathrm{T}_{\mathrm{S}}$ activity beyond antigen binding will be dealt with in a later section.

7. GAT-TS $F$ in Responder Strains. The data described above showing that $\mathrm{H}-2$ controlled defects in $\mathrm{T}_{\mathrm{S}} \mathrm{F}$ production exist in the GT model, and that nonresponder derived GAT- $\mathrm{T}_{\mathrm{S}} \mathrm{F}$ could activate $\mathrm{T}_{\mathrm{S}_{2}}$ in responder mice raised the question of whether GAT responder mice lacked the ability to produce their own $T_{S} F$, thus accounting in part for their responder status. This issue was investigated in vitro. Evidence pointing to $\mathrm{Ir}$ gene function at the level of macrophage $(\mathrm{M} \emptyset)-\mathrm{T}_{\mathrm{H}}$ interaction $[10,85,119]$, together with studies suggesting that antigens which bypassed $M \emptyset$ were efficient at $T_{S}$ induction $[6,58,60]$, led to attempts to produce GAT- $T_{S}$ with responder spleen cells depleted of antigen presenting cells $(\mathrm{M} \emptyset)$ [104]. Such cells generated active, GAT specific $T_{S}$ when exposed even to low $(5-10 \mu \mathrm{g} / \mathrm{ml})$ concentrations of GAT for two days in vitro. Higher concentrations of GAT (50 $\mu \mathrm{g} / \mathrm{ml}$ ) could induce $T_{S}$ even when $\mathrm{M} \emptyset$ were not removed from the spleen cell preparation. The $T_{S}$ induced under $M \emptyset$-depleted conditions were then washed and recultured for $24 \mathrm{~h}$ in the absence of additional antigen. The cell free supernatant of such $T_{S}$ cultures was found to mediate suppresion in vitro GAT responses. The material responsible for this suppression, which is GAT specific and acts across $\mathrm{H}-2$ barriers, bears I-J subregion coded determinants and has antigen-binding activity. Further, these $T_{S} F$ containing supernatants also induce $T_{S_{2}}$ under the same conditions as nonresponder $\mathrm{T}_{\mathrm{S}} \mathrm{F}$ derived by sonication. Thus, it appears that GAT 
responder mice can produce GAT- $\mathrm{T}_{\mathrm{S}} \mathrm{F}$ which shares virtually all of the features of the GAT- $\mathrm{T}_{\mathrm{S}} \mathrm{F}$ obtained from in vivo stimulated nonresponder $\mathrm{T}_{\mathrm{S}}$ [105]. This responder $T_{S} F$ has the additional property of directly suppressing responder GAT PFC responses, while nonresponder GAT- $T_{S} F$ must first induce $T_{S_{2}}$ to affect responder immunity. Whether this difference reflects the different methods of $T_{S} F$ preparation (in vitro versus in vivo) or a more fundamental difference between $T_{S} F$ derived from responder and nonresponder mice has not been ascertained.

Kontiainen et al. have recently reported on their investigations concerning polypeptide specific $T_{S} F$. Using the same in vitro model as employed to study $\mathrm{KLH}$ specific $T_{S} F$, these workers showed, in agreement with the data just discussed, that responder and nonresponder spleen cells cultured with high concentrations of GAT or $(T, G)-A-L(100 \mu \mathrm{g} / \mathrm{ml})$ generated $T_{S}[51]$, which released specific $T_{S} F$ into the culture supernatant [78]. The action of these GAT and (T, G)-A $-\mathrm{L} \mathrm{T}_{\mathrm{S}} \mathrm{F}$ appears to be mediated at least in part by inhibition of $T_{H}$ function, since they suppress both polypeptide and DNP-polypeptide PFC responses. No information is available on the question of whether these factors act directly on $\mathrm{T}_{\mathrm{H}}$, or via $\mathrm{T}_{\mathrm{S}_{2}}$ induction, or both. It is clear, however, from the data of Kontiainen et al. and ourselves, that both responder and nonresponder animals can produce $\mathrm{T}_{\mathrm{S}} \mathrm{F}$ to antigens under $\mathrm{H}-2$ linked Ir gene control. Future studies will undoubtedly resolve the question of whether responder $T_{S} F$ differs from nonresponder $T_{S} F$, and the issue of the existence of one or more specific, $\mathrm{I}-\mathrm{J}^{+} \mathrm{T}_{\mathrm{S}} \mathrm{F}$ in these suppressor materials, each with a distinct mode of action.

\section{C. $T_{S} F$ Active on Cell-Mediated Immune Responses}

Another important area of research on suppressor cell function involves contact hypersensitivity or delayed type hypersensitivity to chemically reactive small molecules ("haptens") or derivatized syngeneic cells. These experimental systems have been particularly revealing insofar as suppressor factors are concerned.

1. TNP and DNP $T_{S} F$. The earliest work in this area was carried out by Asherson and Zembala. They demonstrated that lymph node cells from mice given picryl sulfonic acid (PSA) [trinitrobenzenesulfonic acid (TNBS)] iv. contained suppressor $T$ cells which when cotransferred with lymphocytes from mice primed with picryl chloride (PC1) diminished the adoptive transfer of contact sensitivity $[1,154]$. If $\mathrm{T}_{\mathrm{S}}$ containing lymph node cells were obtained on day 6 from mice receiving PSA iv on day 0 and a cutaneous challenge with $\mathrm{PC} 1$ on day 5 , these $\mathrm{T}_{\mathrm{S}}$ released in culture over the next $48 \mathrm{~h}$ a soluble material which could also depress the adoptive transfer of responsiveness to $\mathrm{PC} 1$ [155]. This soluble material was not released by cells from mice receiving only PSA iv or PC1 cutaneously - both steps were necessary. The PC1-induced $\mathrm{T}_{\mathrm{S}} \mathrm{F}$ did not interfere with transfer of immunity to oxazalone (OX), a distinct immunogen, demonstrating the functional antigen-specificity of this factor. This specificity was consistent with later experiments showing that the active material in the supernatant possessed specific binding affinity for TNP but not oxazalone conjugated beads [3]. It was also shown that the $T_{S} F$ had a mol. wt. of about 50000 , was relatively insensitive to trypsin or heating as compared with other $\mathrm{T}_{\mathrm{S}} \mathrm{F}$, contained carbohydrate (based on binding to Con A-Sepharose), and also possessed $\mathrm{H}-2$ coded determinants $[3,156]$. 
Studies on the mechanism of action of $\mathrm{TNP}-\mathrm{T}_{\mathrm{S}} \mathrm{F}$ revealed two apparently distinct modes of action. If $\mathrm{PC} 1$ immune lymph node cells were directly incubated in TNP-T $\mathrm{T}_{\mathrm{S}} \mathrm{F}$, the response to PC1 was decreased upon transfer. Incubation of OXimmune cells in TNP- $\mathrm{T}_{\mathrm{S}} \mathrm{F}$ had no effect on transfer, whether or not the challenge included PC1 as well as OX. This fine specificity was not observed, however, if peritoneal exudate cells (PEC) were first incubated in TNP-T ${ }_{S} F$, and these PEC then cotransferred with the PC1 or OX-immune cells. Under these conditions, PC1 and not $\mathrm{OX}$ immunity was decreased when only $\mathrm{PC} 1$ or $\mathrm{OX}$, but not both, were used for challenge. However, if both PC1 and $\mathrm{OX}$ were used challenge OX immune cells, the response was suppressed by the TNP-T $\mathrm{F}$ treated PEC. Thus, Zembala and Asherson concluded that after "arming" by TNP-T $\mathrm{T}_{\mathrm{S}} \mathrm{F}$, exposure of such PEC to antigen led to the activation of an antigen-nonspecific suppressor mechanism mediated by the macrophages in the PEC population [2]. These data are consistent with recent reports from Ptak et al. showing a role for M $\emptyset$ binding of "suppressor signals" in vitro [106], and the demonstration of a low molecular weight $(10-30,000)$ material released from "armed" $M \emptyset$ which nonspecifically suppresses contact sensitivity responses [107]. They also are similar to the results of Tada [123], insofar as the nonspecific suppression evoked by stimultaneous exposure of $T_{S} F$ treated cells to the antigen recognized by the $T_{S} F$ and the antigen being used as the immunogen.

Moorhead adopted the general protocol of Asherson and Zembala in studying $\mathrm{T}_{\mathrm{S}} \mathrm{F}$ specific for $\mathrm{DNP}$ [87-90]. This $\mathrm{T}_{\mathrm{S}} \mathrm{F}$ is produced by $\mathrm{T}$ cells from mice given dinitrophenyl sulfonic acid iv and challenged with dinitrofluorobenzene prior to culture. It is assayed by its ability to decrease the transfer of contact sensitivity to DNFB by immune lymph node cells incubated in the factor. Affinity chromatography studies demonstrated that this $T_{S} F$ is specific for DNP and does not recognize the closely related compound TNP. Further, the $\mathrm{T}_{\mathrm{S}} \mathrm{F}$ lacks Ig determinants, but possesses $\mathrm{H}-2$ coded determinants. Of great interest are very recent data showing that this DNP-T $\mathrm{S}$ lacks I-J determinants, but appears to posses I-C subregion coded alloantigenic determinants [90]. DNP suppressor factor does not seem to be associated with antigen, as is GAT- $\mathrm{T}_{\mathrm{S}} \mathrm{F}$, since $\mathrm{DNP}-\mathrm{T}_{\mathrm{S}} \mathrm{F}$ is not bound by anti-DNP antibody absorbents [87]. However, the possibility that the $T_{S} F$ is associated with univalent DNP moieties cannot be ruled out by this method. An intriguing finding in Moorhead's studies is that DNP- $\mathrm{T}_{\mathrm{S}} \mathrm{F}$ is $\mathrm{H}-2$ restricted in its activity [88]. Exposure of DNFB-immune cells to DNP-T $\mathrm{T} F$ results in suppresion of immunity only if the treated cells share $\mathrm{H}-2 \mathrm{~K}$ or $\mathrm{H}-2 \mathrm{D}$ identity with the $\mathrm{T}_{\mathrm{S}} \mathrm{F}$ donor. Furthermore, although DNP-T $\mathrm{S}_{\mathrm{S}} \mathrm{can}$ be adsorbed by DNP-KLH columns in the absence of added $\mathrm{H}-2$ products, it only can be adsorbed by DNP-conjugated cells sharing $\mathrm{H}-2 \mathrm{~K}$ and/or $\mathrm{H}-2 \mathrm{D}$ genes with the $\mathrm{DNP}_{\mathrm{S}} \mathrm{F}$ donor [89]. These data raise important questions concerning the interpretation of the binding to DNP-KLH and the nature of combining site(s) of the $T_{S} F$. These data are also consistent with the results of Tada and coworkers showing a requirement for $\mathrm{H}-2$ compatibility between $\mathrm{T}_{\mathrm{S}} \mathrm{F}$ donor and target cell for $\mathrm{KLH}-\mathrm{T}_{\mathrm{S}} \mathrm{F}$ [126], but differ with respect to the $\mathrm{H}-2$ region involved (K/D for DNP- $\mathrm{T}_{\mathrm{S}} \mathrm{F}$ and I-J for KLH-T $\mathrm{K}$ ). Miller et al. [84] have reported that transfer of DNP-specific $T_{S}$ stimulated by DNP cells leads to suppresion only if the recipient matches the $\mathrm{T}_{\mathrm{S}}$ donor at $\mathrm{H}-2 \mathrm{D}$, confirming in part the results of Moorhead using $\mathrm{T}_{\mathrm{S}} \mathrm{F}$. It may be of some importance that many studies 
have documented the role of $\mathrm{H}-2 \mathrm{~K}$ and $\mathrm{D}$ products as target or restricting antigens for cytolytic T lymphocytes stimulated with haptenated (TNP, DNP, etc.) syngeneic cells [119]. This may indicate that the K/D molecules are particularly important for Ly $2,3^{+}$effector function involving these haptens, either as CTL or $\mathrm{T}_{\mathrm{S}}$ producing $\mathrm{T}_{\mathrm{S}} \mathrm{F}$. These data, and those to be presented below concerning a $\mathrm{T}_{\mathrm{S}} \mathrm{F}$ for mixed lymphocyte reactions, clearly demonstrate that although $\mathrm{H}-2$ genes are important in $\mathrm{T}_{\mathrm{S}} \mathrm{F}$ function, no one subregion is unique in this regard, and in some cases, no restriction for $T_{S} F$ activity can be seen (e.g., GAT- $T_{S} F$ ).

$A$ third series of experiments on hapten specific $T_{S} F$ has been carried out by Greene, Benacerraf, and colleagues. In an early study Greene et al. described a TNP$\mathrm{T}_{\mathrm{S}} \mathrm{F}$ produced by the Asherson-Zembala method which was active when administered in vivo to animals concomitant with $\mathrm{PC} 1$ priming, in contrast to the previous studies employing suppression of the activity of already primed cells in a transfer model. Using this procedure, these authors showed that the TNP- $\mathrm{T}_{\mathrm{S}} \mathrm{F}$ responsible for the observed effects possessed I-J subregion coded determinants [49]. This contrasts with Moorhead's results for $\mathrm{DNP}-\mathrm{T}_{\mathrm{S}} \mathrm{F}$, assayed by inhibition of adoptive immunity [90]. It does not appears, however, that the assay accounts for this difference, since a TNP- $T_{S} F$ assayed in the same manner as the $D N P-T_{S} F$ was found to bear I-J coded determinants [90], as in the study by Greene et al.

2. Suppression of Azobenzenearsonate Specific DTH by $T_{S} F$. More recently, Bach et al. have described the occurrence of suppressor cells and $T_{S} F$ specific for the hapten azobenzenearsonate (ABA). In this experimental model, immunity is induced by sc injection of hapten-derivatized syngeneic spleen cells, and measured as the $24 \mathrm{~h} \mathrm{DTH}$ response to challenge with either haptenated cells or free reactive hapten [4]. Suppressor factor is tested by assessing the decrease in immunity that results from $T_{S} F$ administration at the time of, and for two days following priming [50]. The particular interest in this hapten derives from the investigations of Nisonoff and coworkers, which showed that A/J antibodies to ABA possess a crossreactive idiotype (CRI) on approximately $20-70 \%$ of the anti-ABA molecules [99]. The presence of this idiotype on anti-ABA antibodies is regulated by $\mathrm{V}_{\mathrm{H}}$ (-linked) genes. It was thus of great interest to determine if an $\mathrm{MHC}$ coded, $\mathrm{T}$ cell derived product, $\mathrm{ABA}-\mathrm{T}_{\mathrm{S}} \mathrm{F}$, shared this $\mathrm{CRI}$ with immunoglobulins.

Passage of $A B A-T_{S} F$ derived from $A / J$ mice over an affinity column prepared from purified rabbit anti-Id leads to the partial removal of suppressor activity from the $\mathrm{T}_{\mathrm{S}} \mathrm{F}$ preparation, and this activity can be recovered in the eluate from this column. Control experiments demonstrated that these results truly reflected an idiotype-specific binding of the $A B A-T_{S} F$. These data thus confirm the studies on GAT- $\mathrm{T}_{\mathrm{S}} \mathrm{F}$, demonstrating shared idiotypy between antibodies and $\mathrm{T}$ cell derived, MHC coded suppressor factors. Bach et al. provided an additional piece of evidence, not available in the GAT model, that the idiotypic cross-reaction between anti-ABA antibodies and $A B A-T_{S} F$ was the result of the action of Ig (linked) genes. Thus, ABA-T $\mathrm{T}_{\mathrm{S}} \mathrm{F}$ derived from B10.A mice, which share $\mathrm{H}-2$ with $\mathrm{A} / \mathrm{J}$ mice but differ at background genes including those linked to Ig allotype, fails to bind to the rabbit anti-Id absorbent. Furthermore, $\mathrm{ABA}-\mathrm{T}_{\mathrm{S}} \mathrm{F}$ derived from BALB/c $\left(\mathrm{Ig}-1^{\mathrm{a}+}\right)$ mice is idiotype-negative, while $\mathrm{ABA}-\mathrm{T}_{\mathrm{S}} \mathrm{F}$ from the congeneic partner strain C.AL-20 $\left(\operatorname{Ig}-1^{\mathrm{d} / \mathrm{e}}\right)$, which shares much of its Ig genetic region with $\mathrm{A} / \mathrm{J}$, is CRI positive [5]. 
These findings have important implications for the structure of $T_{S} F$, and the involvement of $\mathrm{Ig}$ genes in the construction of $\mathrm{T}$ cell-derived antigen binding molecules.

Additional studies on $\mathrm{ABA}-\mathrm{T}_{\mathrm{S}} \mathrm{F}$ have revealed several interesting facts. Sy et al. [121] in these laboratories have recently shown, by the use of $\mathrm{PL} / \mathrm{J}$ mice which lack the $\mathrm{V}_{\mathrm{K}}$ region usually associated with $\mathrm{CRI}^{+}$anti-ABA antibodies, that $\mathrm{CRI}^{+} \mathrm{ABA}$ $\mathrm{T}_{\mathrm{S}} \mathrm{F}$ does not apparently utilize such a light chain product. In addition, $\mathrm{ABA}-\mathrm{T}_{\mathrm{S}} \mathrm{F}$ has been shown to induce $T_{S_{2}}$, as reported earlier for the GAT, GT, and KLH models. However, although these $\mathrm{T}_{\mathrm{S}_{2}}$ are part of an ABA specific suppressor pathway, they cannot be lysed by anti-idiotype and $\mathrm{C}$, in contrast to the $\mathrm{T}_{\mathrm{S}_{1}}$ cells producing $\mathrm{ABA}-\mathrm{T}_{\mathrm{S}} \mathrm{F}$, which are $\mathrm{CRI}^{+}$. In studying the reason for the absence of detectable $\mathrm{CRI}^{+}$molecules on $\mathrm{T}_{\mathrm{S}_{2}}$ it was found that $\mathrm{T}_{\mathrm{S}_{2}}$ could be bound to plastic dishes coated with $\mathrm{CRI}^{+}$antibody, and not to ABA-BSA coated plates. The opposite was true for $A B A$ specific, $T_{S} F$-producing $T_{S_{1}}[122]$. Finally, $A B A-T_{S} F$ could be shown to be able to suppress across an $\mathrm{H}-2$ but not across an allotype barrier [23]. Thus, it would seem that $\mathrm{CRI}^{+} \mathrm{ABA}-\mathrm{T}_{\mathrm{S}} \mathrm{F}$ acts by triggering a population of anti-idiotypic $\mathrm{T}_{\mathrm{S}_{2}}$. These data have fundamental importance in understanding the role of $\mathrm{T}_{\mathrm{S}} \mathrm{F}$ in suppressor activity.

\section{D. $T_{S} F$ in Tumor Immunity}

Greene and coworkers have studied $\mathrm{T}_{\mathrm{S}} \mathrm{F}$ in another cell mediated system. Fujimoto et al. demonstrated that $\mathrm{A} / \mathrm{J}$ mice bearing the syngeneic tumor $\mathrm{S} 1509 \mathrm{a}$ possess $\mathrm{T}_{\mathrm{S}}$ which specifically enhance tumor growth when adoptively transferred to $\mathrm{A} / \mathrm{J}$ mice hyperimmune to $\$ 1509$ and bearing a tumor graft destined to be rejected [36, 37]. Thus, in this system, $\mathrm{T}_{\mathrm{S}}$ interfere with already established tumor immunity. Greene et al. found that disruption of lymphoid cell populations containing S1509a-specific $\mathrm{T}_{\mathrm{S}}$ yielded a soluble material with the ability to enhance tumor growth under the same conditions as $\mathrm{T}_{\mathrm{S}}$ themselves [35]. This $\mathrm{T}_{\mathrm{S}} \mathrm{F}$ was a protein of about $50,000 \mathrm{~mol}$. wt. which bore $\mathrm{H}-2$ coded determinants and could be specifically adsorbed by $1509 \mathrm{a}$ tumor cells [48]. Recently, Perry et al. have found that this $\mathrm{T}_{\mathrm{S}} \mathrm{F}$ bears I-J subregion coded determinants [103]. In this system also, administration of $10 \times 10^{6}$ cell equivalents of $\mathrm{T}_{\mathrm{S}} \mathrm{F}$ per day for four days to normal $\mathrm{A} / \mathrm{J}$ mice stimulates the appearance of $1509 \mathrm{a}$ specific $\mathrm{T}_{\mathrm{S}_{2}}$ in the spleens of the treated mice, demonstrating in a potentially clinically relevant model the same $T_{S}$ pathway described in more basic model systems.

\section{E. $T_{S} F$ in Mixed Lymphocyte Responses (MLR)}

A final type of $T_{\mathrm{S}} \mathrm{F}$ active in diminishing a cell mediated type of immune response is the MLR suppressor factor described by Rich and Rich. Although this material differs from all the above in not showing antigen specificity, the similarities of its means of elicitation, immunochemical properties, and genetics argue for its inclusion here. Suppressor T cells are prepared by immunizing a mouse with allogeneic lymphoid cells administered in the hind footpads. Four days later, the spleen cells from such a mouse will suppress the response of syngeneic lymphoid cells to any allogeneic stimulator [108]. If these $T_{S}$ containing spleen cells are cultured for $24 \mathrm{~h}$ in the presence of allogeneic cells of the same $\mathrm{H}-2$ type as the original 
immunogen, a soluble factor is released into the culture supernatant which suppresses any MLR of responder cells syngeneic with the $T_{S}$ [109]. This soluble material does not bind to cells bearing the $\mathrm{H}-2$ antigens of the immunogen responsible for the $\mathrm{T}_{\mathrm{S}} \mathrm{F}$ production. MLR $\mathrm{T}_{\mathrm{S}} \mathrm{F}$ does have three interesting properties: (1) it only suppresses MLR of responding cells sharing the I-C subregion with the $\mathrm{T}_{\mathrm{S}} \mathrm{F}$ producing cells, (2) it can be adsorbed by I-C compatible cells when these cells are either Con-A activated thymocytes or alloantigen activated spleen cells, but not if the cells are unactivated - this activation can occur within $4 \mathrm{~h}$ of exposure to alloantigen, and (3) the factor bears determinants coded by the I-C, not I-J, subregion $[110,111,113]$.

The lack of antigen specificity of this $\mathrm{T}_{\mathrm{S}} \mathrm{F}$ may truly reflect the absence of an antigen binding site, making this $\mathrm{T}_{\mathrm{S}} \mathrm{F}$ of great interest for structural comparison to the other antigen-binding $T$ cell factor, or may reflect a different (perhaps antiidiotypic) specificity from the conventional anti-antigen specificity of other $T_{S}$. Lastly, Rich and Rich have documented that even though this $\mathrm{T}_{\mathrm{S}} \mathrm{F}$ bears I-C subregion coded determinants, genes outside of $\mathrm{H}-2$ play an important role in $\mathrm{T}_{\mathrm{S}} \mathrm{F}$ production [112]. Thus, B6 mice fail to give MLR- $T_{S} F$ under standard conditions, but nonethless are suppressed by $\mathrm{T}_{\mathrm{S}} \mathrm{F}$ from other $\mathrm{H}-2^{\mathrm{b}}$ strains. $(\mathrm{B} 6 \times \mathrm{BALB} / \mathrm{c}) \mathrm{F}_{1}$ mice produce $\mathrm{T}_{\mathrm{S}} \mathrm{F}$ active on both $\mathrm{H}-2^{\mathrm{b}}$ and $\mathrm{H}-2^{\mathrm{d}}$ strains, however, indicating that $\mathrm{B} 6$ mice can produce $T_{S} F$ (i. e., possess the structural gene for the I-C restricted factor) but lack an effective non- $\mathrm{H}-2$ coded regulatory gene affecting $\mathrm{T}_{\mathrm{S}} \mathrm{F}$ production. This situation is similar to that described by Taniguchi et al. [134] for $K L H-T_{S} F$ production by $\mathrm{B} 10$ congenics, and may indicate a general phenomenon of non- $\mathrm{H}-2$ gene regulation of $\mathrm{H}-2$ gene activity.

\section{Conclusion}

\section{A. Molecular Characteristics of Antigen-Specific T Cell Factors}

The data presented above point out the many similarities in structure and antigenic determinants of various $\mathrm{T}$ cell factors active in immune regulation. The known features of these materials can be divided into four main categories: (1) size, (2) presence of MHC determinants, (3) presence of $\operatorname{Ig} \mathrm{C}_{\mathrm{H}}$ and $\mathrm{V}_{\mathrm{H}}$ determinants, and (4) antigen binding capacity and specificity (see summary in Table 1).

All antigen-specific MHC coded $\mathrm{T}$ cell factors studied to date have nominal molecular weights in the 40000-60000 dalton range. The lack of precision in the actual mol. wt. probably derives from several sources. At present, most sizing data are based on gel filtration of crude or partially purified factors, followed by bioassay of the fractions from the column. This method is adequate only to give a rough estimate of true molecular size. It further suffers from the fact that many factors tested this way may be associated with antigen fragments [145], which contribute to the apparent mol. wt. and apparent heterogeneity in size of the true T cell product. A final source of difficulty in this area is the fact that none of the mol. wt. determinations on $\mathrm{T}$ cell factors has been carried out on material isolated under conditions preventing potential proteolysis. Binz and Wigzell, in their studies on idiotype bearing $\mathrm{T}$ cell receptors for alloantigens, found that their $\mathrm{T}$ cell material 
Table 1. Molecular characteristics of $\mathrm{T}_{\mathrm{H}} \mathrm{F}$ and $\mathrm{T}_{\mathrm{S}} \mathrm{F}$

\begin{tabular}{|c|c|c|c|c|c|}
\hline \multirow{2}{*}{$\frac{\text { Factor type }}{(\mathrm{T}, \mathrm{G})-\mathrm{A}-\mathrm{L}-\mathrm{T}_{\mathrm{H}} \mathrm{F} \text { (in vivo) }}$} & \multicolumn{2}{|c|}{$\begin{array}{l}\text { Antigen } \\
\text { binding specificity Size }\end{array}$} & \multicolumn{2}{|c|}{$\begin{array}{l}\text { I-region } \\
\text { determinants } \mathrm{C}_{\mathrm{H}}, \mathrm{C}_{\mathrm{L}}\end{array}$} & \multirow{2}{*}{$\frac{\mathrm{V}_{\mathrm{H}}(\mathrm{Id})}{+}$} \\
\hline & $\mathrm{G}-\mathrm{A}-\mathrm{L}$ & $\sim 50000$ & $\mathrm{I}-\mathrm{A}$ &,-- & \\
\hline$(\mathrm{T}, \mathrm{G})-\mathrm{A}-\mathrm{L}-\mathrm{T}_{\mathrm{H}} \mathrm{F}$ (in vitro) & $(\mathrm{T}, \mathrm{G})-\mathrm{A}-\mathrm{L}$ & $\sim 50000$ & I &,-- & NT \\
\hline (T, G)-Pro- $-\mathrm{L}-\mathrm{T}_{\mathrm{H}} \mathrm{F}$ (in vivo) & $(\mathrm{T}, \mathrm{G})$-Pro $-\mathrm{L}$ & NT & $\mathrm{I}-\mathrm{A}$ &,-- & $\mathrm{NT}$ \\
\hline $\mathrm{KLH}_{-} \mathrm{T}_{\mathrm{a}} \mathrm{F}$ (in vivo) & KLH & $30-50000$ & $\mathrm{I}-\mathrm{A}$ &,-- & NT \\
\hline GAT-T ${ }_{S} \mathrm{~F}$ (in vivo) & $\mathrm{GAT}>>\mathrm{GT}$ & $40-50000$ & $\mathrm{I}-\mathrm{J}$ &,-- & $+(\mathrm{CGAT}$ \\
\hline $\mathrm{GT}-\mathrm{T}_{\mathrm{S}} \mathrm{F}$ (in vivo) & $\mathrm{GT}>>\mathrm{GAT}$ & $\sim 50000$ & $\mathrm{I}-\mathrm{J}$ &,-- & NT \\
\hline $\mathrm{KLH}-\mathrm{T}_{\mathrm{S}} \mathrm{F}$ (in vivo) & KLH & $35-60000$ & $\mathrm{I}-\mathrm{J}$ &,-- & $+\left(V_{\mathrm{H}}\right.$ framework $)$ \\
\hline $\mathrm{H} \gamma \mathrm{G}-\mathrm{T}_{S} \mathrm{~F}$ (in vivo) & $\mathrm{H} \gamma \mathrm{G}$ & $30-55000$ & I &,-- & NT \\
\hline $\mathrm{TNP}_{\mathrm{S}} \mathrm{T}$ F (in vivo) & TNP & $\sim 50000$ & $\mathrm{I}-\mathrm{J}$ &,-- & NT \\
\hline${ }_{D N P}-T_{S} F$ (in vivo) & DNP & NT & $\mathrm{I}-\mathrm{C}$ &,-- & NT \\
\hline $\mathrm{ABA}-\mathrm{T}_{\mathrm{S}}^{\mathrm{F}} \mathrm{F}$ (in vivo) & $\mathrm{ABA}$ & $38-68000$ & I &,-- & $+\begin{array}{l}\mathrm{A} / \mathrm{J} \\
\mathrm{CRI}\end{array}$ \\
\hline $\mathrm{S} 1509 \mathrm{a}-\mathrm{T}_{\mathrm{S}} \mathrm{F}$ (in vivo) & TAA of $\mathrm{S} 1509 \mathrm{a}$ & $<70000$ & I-J &,-- & NT \\
\hline MLR-T $\mathrm{S}_{\mathrm{S}} \mathrm{F}$ (in vivo) & None known & NT & $\mathrm{I}-\mathrm{C}$ & NT & NT \\
\hline
\end{tabular}

was rapidly degraded from 75000 to $30-40000$ dalton pieces by protease in serum [11]. These results strongly suggest that $\mathrm{T}$ cell factors, derived from cell sonicates or produced in vitro with high cell density or in serum, may also be partially degraded before they are analyzed, perhaps leading to a falsely low estimate of mol. wt. However, it must be noted that insofar as factors are concerned, since the sizing is based on functional assays, both the antigen binding and regulatory properties are retained in a molecular structure of no more than about 50000 daltons. The actual size of $\mathrm{T}$ cell factors will probably best be determined by analytic biochemical techniques such as SDS-PAGE, using purified (antigen free) materials derived in the presence of protease inhibitors from either $\mathrm{T}$ cells or $\mathrm{T}$ cell hybridomas. One study of $\mathrm{T}_{\mathrm{S}} \mathrm{F}$ by this approach has been published $[143,144]$. A single hybridoma was derived which produced a sheep erythrocyte specific $T_{S} F$ active in vitro on $P F C$ responses. The hybridoma cells were grown in radioactive amino acids and SRBC binding material from these labeled cells was isolated and analyzed on SDS-PAGE gels. The results indicated a molecule composed of two noncovalently associated chains, a larger chain of 85000 daltons with antigen-binding activity, and a smaller chain of 25000 daltons devoid of anti-SRBC activity, but bearing $\mathrm{H}-2$ coded determinants.

All the factors discussed in this chapter bear determinants coded for by genes in the I-region of the H-2 complex. At least three distinct genes have been implicated in construction of ' $T$ cell factors: one in the I-A subregion coding for determinants on $\mathrm{T}_{\mathrm{a}} \mathrm{F}[149]$ and $\mathrm{T}_{\mathrm{H}} \mathrm{F}[52,57]$, and one each in the I-J and I-C subregions coding for determinants on $\mathrm{T}_{\mathrm{S}} \mathrm{F}[49,90,113,126,137,146]$. The role of these MHC gene products in the regulatory function of the factors in unknown at present. However, the association of the I-A subregion with helper function and the I-J/I-C subregions with suppressor activity, regardless of the antigen specificity of the factor involved, indicates that these MHC products are probably important in the biologic effector function of these factors, possibly in a manner analogous to the various effector 
functions of the $F_{c}$ portions of immunoglobulins of different isotypes. This analogy would also apply to the observation of restricted interactions of certain factors with their target cells, just as different cells have $F_{c}$ receptors with affinity for one or another isotype. These $\mathrm{MHC}$ restricted interactions will be discussed further below in relation to the mechanism of factor activity. An important point to keep in mind, however, is that the I subregion definitions rely on the detection and preservation of what at present must be considered random recombination events. Thus, if there is more than one gene in each subregion that can participate in factor construction, for certain antigens, one may find " $\mathrm{I}-\mathrm{J}$ " determinants on a helper factor [54] or, as for the MLC and DNP factors, "I-C" determinants on a suppressor factor, simply because the relevant functional gene is to the right (or left) of the crossover event defining the various subregions. In other words, although in general regulatory function will be associated with subregion assignment, exceptions should be expected for some antigens, as the number of factors studied increases. It will require more precise antisera (perhaps from hybridomas) defined on a functional rather than genetic basis, or detailed structural studies on the MHC portion of $T$ cell factors, to determine how products with similar function but different genetic origins may actually be related.

Two final issues concerning the involvement of I region gene products in factor structure also need to be discussed. First, although it is generally believed that the structures bearing I region coded determinants in factor molecules are polypeptide chains, some experiments have been interpreted as suggesting that the serologically detectable Ia antigens on factors may be carbohydrate, not protein, in nature [54]. Second, as recently pointed out by Schrader [114], one cannot rule out on the basis of available data, that $\mathrm{T}$ cells factors do not contain I region gene products, but rather, that the alloantisera used to bind the factors contain anti-idiotypic antibodies which are detecting binding sites on the factor molecules with anti-self Ia specificity. It should be kept in mind, however, that if this hypothesis was true, it would be necessary to postulate that such anti-self Ia receptor(s) had their idiotypic structures dictated solely by the $\mathrm{H}-2 \mathrm{I}$ region of the factor producer, independently of its $\mathrm{V}_{\mathrm{H}}$ gene cluster, since the binding of factors to anti-Ia immunoadsorbents is strictly determined by $\mathrm{H}-2 \mathrm{I}$ and not background (including allotype-linked) genes. Also, such a view is difficult to reconcile with the findings that most factors act with undiminished effeciency across $\mathrm{H}-2$ barriers $[65,76,150]$, while this theory suggests the likelihood of strict $\mathrm{H}-2$ restrictions, such as those seen for KLH-T $\mathrm{F}$ by Tada et al. [126]. Studies using hybridoma reagents and chimeras will aid in testing the validity of this intriguing suggestion.

The issue of Ig determinants on T cell factors is also a complicated one. Early reports on $\mathrm{T}$ cell helper factor by Feldmann and Basten suggested a molecule resembling $7 \mathrm{~S} \mathrm{IgM}$, and possessing certain constant region determinants of normal immunoglobulins [30]. More recently, all laboratories studying $\mathrm{T}$ cell-derived materials bearing MHC determinants have demonstrated an absence of $\mathrm{C}_{\mathrm{H}}$ and $\mathrm{C}_{\mathrm{L}}$ markers on these factors, when mammalian heteroantisera (e. g., rabbit or goat antimouse Ig) are used. A few reports that chicken anti-mouse Ig can bind T cell factors [33] have not been confirmed, and the issue of recognition of carbohydrate, rather than protein, determinants by such sera is not yet resolved. Thus, at present, it seems reasonable to conclude that the MHC determinant-bearing $\mathrm{T}$ cell factors lack 
constant region products of either $H$ or $L$ type. The opposite conclusion has been reached concerning $\mathrm{V}_{\mathrm{H}}$ associated structures. In agreement with direct studies of cell bound receptor material $[12,13,80]$, several groups have documented idiotypic cross-reaction between $T$ cell factors and antibodies directed toward the same antigen $[5,42,47,94]$. The existence of these idiotypic relationships raises the possibility that in addition to $\mathrm{MHC}$ gene products, $\mathrm{T}$ cell regulatory factors possess $\mathrm{V}_{\mathrm{H}}$ gene products, presumably as their antigen binding portions. If this is the case, several models of the structure of these factors can be imagined. The simplest structure would consist of a single chain, composed of a $V$ region using the same $V$ region pool as immunoglobulins and a covalently (peptide bond) linked constant region responsible for biologic effector function and coded for by $\mathrm{MHC}$ genes. This model is, however, rather complex genetically, as it requires the integration into a single polypeptide chain of gene products from distinct chromosomes. A second model would divide the functions of the molecule in the same fashion, but involve either a disulfide or noncovalent association of two polypeptide chains, one bearing a $V_{H}$ associated structure (with or without a $T$ cell specific constant region), the other the MHC coded product. A variant of this model would include a third chain, associated with the $\mathrm{V}_{\mathrm{H}}$-structure and contributing to antigen specificity, i. e., a light chain homologue. This possibility is based on recent observations of heteroclitic behavior of $\mathrm{T}$ cells and their products in mice of $\mathrm{Ig}-1^{\mathrm{b}}$ allotype immunized with NP compounds $[79,153]$. The presence of heteroclitic binding by anti-NP antibodies to NIP requires the participation of a $\lambda$ light chain [71], and thus, a similar structure may be involved in the $T$ cell combining site. Finally, a single chain containing the $\mathrm{V}_{\mathrm{H}}$ region shared with $\mathrm{Ig}$, to which a carbohydrate side chain possessing the Ia determinant is attached, is a possibility.

Certain caveats must be mentioned in evaluating these suggestions. At present, the possible involvement of $\mathrm{V}_{\mathrm{H}}$ genes in factor construction is based largely on idiotypic cross-reactions. Only one study showing genetic linkage of factor idiotype with Ig genes has been reported [5]. It is thus still formally possible that there is simply a great deal of structural similarity in the combining portion of antibodies and specific $\mathrm{T}$ cell factors, accounting for idiotypic cross-reactions, and that identical $V$ genes are not used by both molecules. This issue will be resolved by further genetic study of $T$ cell factors and by direct biochemical (perhaps sequence) comparison of antibody and factor specific for the same antigen.

This question of the genetic origin of the factor combining site is related to studies on factor antigen fine specificity. In several models, the ability of $\mathrm{T}$ cell factors to bind to antigen is distinct from that of antibody from the same animals. Thus, anti-GAT antibody is virtually all GT reactive [63], yet only a fraction of GAT $-T_{S} F$ binds to GT [145], and the suppression mediated by GAT- $T_{S} F$ clearly distinguishes functionally between GAT and GT [41]. Similarly, antibodies to ( $\mathrm{T}, \mathrm{G})-\mathrm{A}-\mathrm{L}$ and (Phe, G)-A - $\mathrm{L}$ are distinct, as is the Ir gene pattern, yet the in vivo derived $(T, G)-A-L T_{H} F$ shows no ability to distinguish between these two polymers [56]. It would therefore appear that either $T$ cell factors do not actually use $I g \mathrm{~V}_{\mathrm{H}}$ genes, or that at a minimum, only certain $\mathrm{V}_{\mathrm{H}}$ genes are used by $\mathrm{T}$ cells in contrast to $\mathrm{B}$ cells, giving a very different spectrum of fine antigen specificity to the two sets of lymphocyte products. Studies on monoclonal $T$ and B cell products from hybridomas or $\mathrm{T}$ cell lines will help approach this question and possibly reveal that 
$\mathrm{V}_{\mathrm{H}}$ regions infrequently used by antibodies are similar or identical to the predominant combining region of the related $\mathrm{T}$ cell product.

\section{B. Functional Analysis of Factor Activity}

1. Models of Factor Mediated Pathways. In order to attempt a synthesis of the data on the mechanism(s) of factor activity, it seems useful to first provide a graphic illustration of each experimental model at the current state of knowledge (Figs. 1-5) and to point out the unique features of each system.

Two types of helper factors (Fig. 1) have been described. Only one report details $\mathrm{T}_{\mathrm{a}} \mathrm{F}$, which has as its target another $\mathrm{T}$ cell, which in turn appears to act as the $\mathrm{T}_{\mathrm{H}}$ for the $B$ cell response [149]. This $T_{a} F$ is derived from a primed Lyt $1^{+}$cell and requires a $T_{H}$ primed to the same antigen as its target. These data stand in distinction to several other $\mathrm{T}_{\mathrm{H}} \mathrm{F}$, which act on $\mathrm{B}$ cells without the need for another $\mathrm{T}$ cell intermediary $[52,139]$. It is possible that these two materials are actually part of a single helper pathway. Feldmann et al. have reported that helper function requires both an Lyt $123^{+}$precursor of an amplifier $\mathrm{T}_{\mathrm{H}}$ and an Ly $1^{+}$helper T cell [32]. The $T_{a} F$ could represent the product of amplifier $T$ cells having matured to an $L y 1^{+}$ phenotype. This $T_{\mathrm{a}} \mathrm{F}$ in turn could act, with $\mathrm{I}-\mathrm{A}$ restriction, on $\mathrm{Ly} 1^{+}$effector $\mathrm{T}_{\mathrm{H}}$ cells, which after triggering by both $T_{a} F$ and antigen release $T_{H} F$. This $T_{H} F$ then acts, together with antigen, to trigger $\mathrm{B}$ lymphocytes. The data available suggest that the $T_{a} F$ is directly adsorbed by and acts on $T$ cells, while for $T_{H} F$, either $M \emptyset$

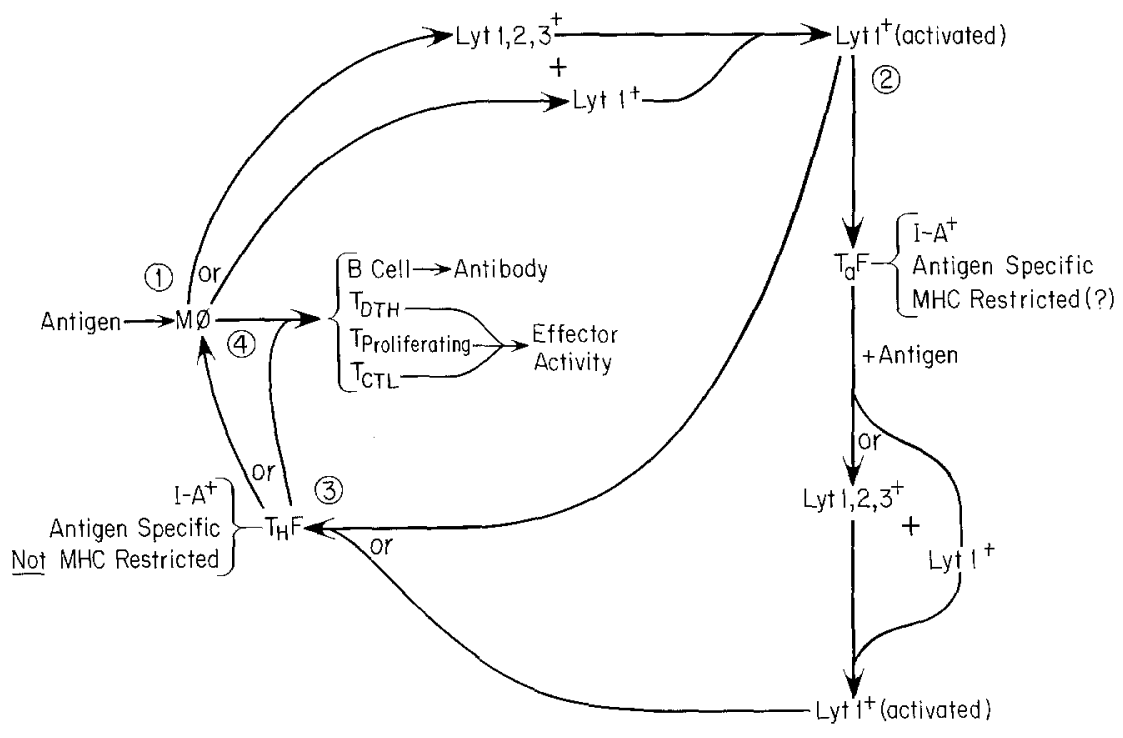

Fig. 1. Helper factor pathways. This figure shows a hypothetical synthesis of the data on $T_{a} F[149]$ and $\mathrm{T}_{\mathrm{H}} \mathrm{F}[32,34,52,53,55,57,73,93,95,96,139-142)$. The word "or" in-between two arrows in this and subsequent figures indicates that the exact pathway is unclear, and either sequence may be correct. $\mathrm{A}$ " + " between two cell types indicates cell-cell interaction at this step in the sequence. We have included a variety of $\mathrm{T}$ cells targets, as well as B cells, since helper cells have been found to play a role in at least some $T$ cell responses of these types 

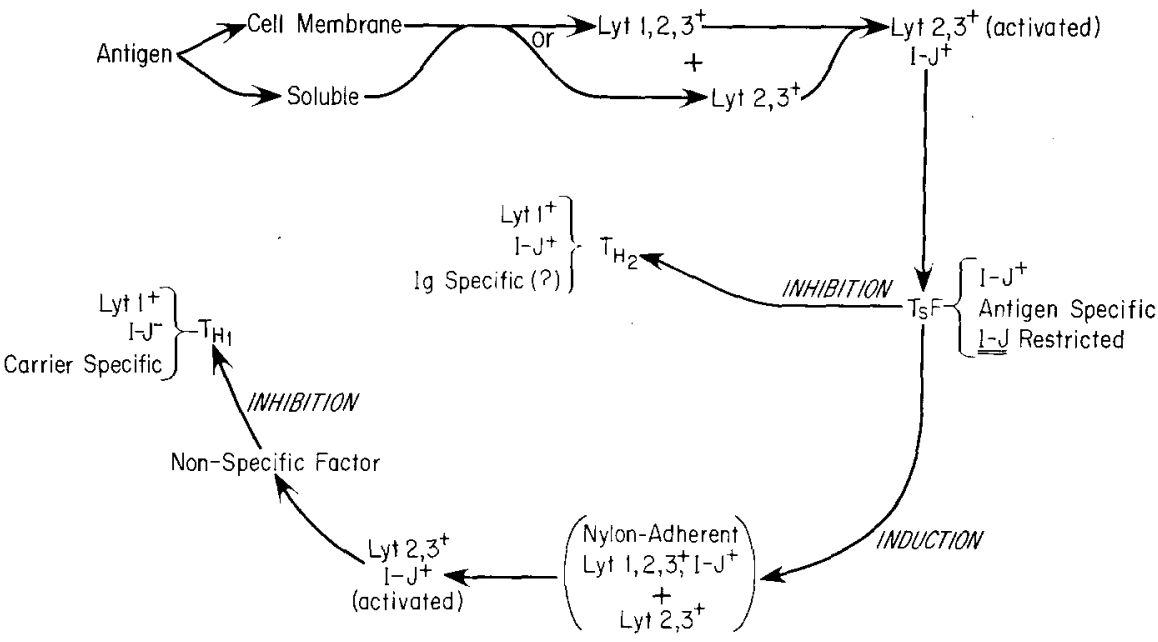

Fig. 2. Suppressor factor pathways for I-J restricted $\mathrm{KLH}-\mathrm{T}_{\mathrm{S}} \mathrm{F}[123,125-134,138]$. The precise mode of activation of the Lyt $2,3^{+} \mathrm{T}_{\mathrm{S}} \mathrm{F}$ producing cell is unclear and is merely suggested in this figure. The action of $T_{S} F$ on two different $T_{H}$ may represent the action of a single moiety, or the individual activities of two unseparated and very similar factors

[53] or B cells [96] adsorb the factor. If the B cell data were in fact due to $\mathrm{M} \emptyset$ in the bone marrow or anti-Thy $1.2+\mathrm{C}$ treated spleen cell preparations used for absorption, this would lead to a single site for $T_{H} F$ function, the $M \emptyset$.

The suppressor systems must be dealt with in a more individual manner. Carrier (KLH) specific $T_{S} F$, as studied by Tada and colleagues $[123,125-134,138]$ (Fig. 2) resembles the factors acting in the GAT, GT, and ABA models in that it has as a major activity the induction of a second set of $T_{S}$ cells, which appear to act as the ultimate $T_{S}$ cell in the pathway (albeit perhaps through a final non- $T$ cell effector). However, one feature serves to distinguish the activity of this type of $\mathrm{KLH}-\mathrm{T}_{\mathrm{S}} \mathrm{F}$ from all other factors. This material shows no detectable activity on either the target cells for its inducing activity, or on $\mathrm{T}_{\mathrm{H}_{2}}$ direct targets, unless these $\mathrm{T}$ cells share I-J subregion markers with the factor donor. Despite deliberate attempts to detect such restrictions, not even a partial limitation of $\mathrm{T}_{\mathrm{S}} \mathrm{F}$ inducing activity by $\mathrm{H}-2 \mathrm{I}$ region genes has been found for other $\mathrm{T}_{\mathrm{S}} \mathrm{F}$.

The second general type of $\mathrm{T}_{\mathrm{S}} \mathrm{F}$ is that found in mice suppressed by GAT, GT, or ABA-syngeneic cells (Fig. 3). In common with KLH-T $\mathrm{F}$, these factors act mainly, if not exclusively by inducing $T_{\mathrm{S}_{2}}$. They differ in acting efficiently across $\mathrm{H}-2$ differences. The most striking feature of these materials, as studied carefully in the ABA model, is that their interaction with pre- $\mathrm{T}_{\mathrm{S}_{2}}$ cells is mediated by anti-idiotypic recognition of the antigen-combining portion of the factor. These data provide a clear-cut verification of the network theory of immunity [59], and demonstrate that such idiotypic interactions may occur between $\mathrm{T}$ cell subsets without the involvement of immunoglobulin. They also point out the extreme potency of at least certain idiotype bearing structures for activating the network, since the amount of $\mathrm{T}_{\mathrm{S}} \mathrm{F}$ needed to suppress a mouse is in fact below the range easily detectable by even 


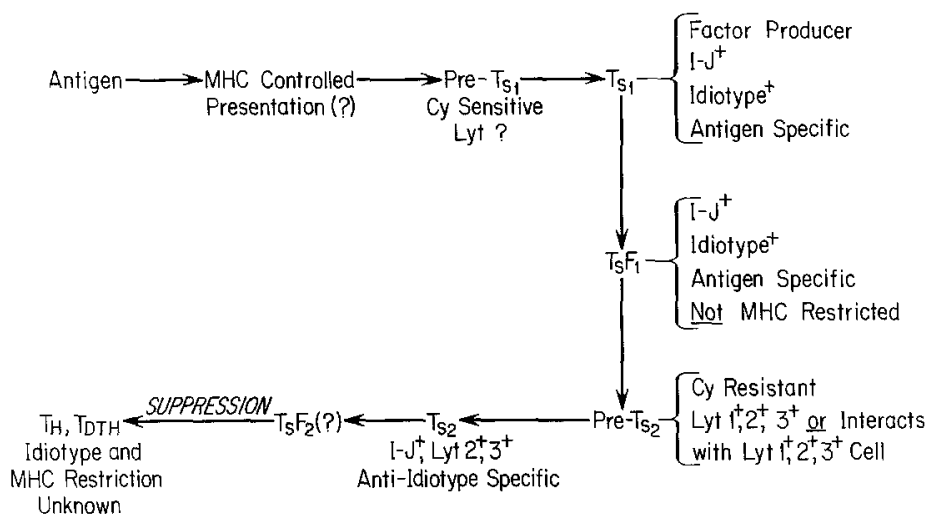

Fig. 3. Suppressor pathways involving inducing-type factors $[5,7-9,20-23,38-43,50,65,68-70,103-$ $105,121,122,145-147,150-152]$. This diagram integrates the findings from the GAT, GT, and ABA models, although not all points have been established in each system. Direct acting $\mathrm{T}_{\mathrm{S}} \mathrm{F}[31-34,73-78$, $143,144]$ may involve the last two steps in the indicated pathway, though perhaps with antigenic not the idiotypic specificity indicated in the figure

standard radioisotopic means. Whether this potency is a result of the biologic properties of a T cell receptor "constant region" perhaps the [-J coded portion of the $\mathrm{T}_{\mathrm{S}} \mathrm{F}$, is unknown at present. Another important feature of this class of $\mathrm{T}_{\mathrm{S}} \mathrm{F}$ is the possible role of antigen presentation in the context of Ia molecules for $T_{S_{1}}$ triggering, and of idiotype-presentation by similar molecules for $T_{S_{2}}$ induction. These issues have been raised by the investigation of the role of Is genes in GT specific suppression, and analysis of this issue will have important implications for understanding the potential anti-self recognition capacities of $\mathrm{T}_{\mathrm{S}_{1}}$ in analogy to other $\mathrm{T}$ cell subsets.

Before leaving this discussion of "inducing" type $T_{S} F$, it is important to detail recent findings in another model of suppressor $T$ cell function not dealt with above. Eardley, Gershon, Cantor, and colleagues [17, 25-27, 46] have reported (Fig. 4) that during the course of an ongoing $\mathrm{T}$ cell dependent immune response, a subset of Lyt $1^{+}$cells is activated which initiates a "feedback" suppressor pathway. Careful investigation of this phenomenon, using an in vitro anti-SRBC model, has shown that the critical Lyt $1^{+}$cells possess both I-J and Qa 1 cell surface markers, and act as inducers of a new set of $T$ cells with distinct differentiation markers [17, 25-27]. This induction appears to be mediated by a soluble factor that is antigen-specific and which bears I-J subregion coded determinants [46]. This materials acts on Lyt $123^{+}, \mathrm{I}-\mathrm{J}^{+}, \mathrm{Qa} 1^{+}$cells to either cause them to differentiate into Lyt $2,3^{+} \mathrm{T}_{\mathrm{S}}$ or to interact with Lyt $2,3^{+}$cells, which in turn secrete a second factor, $\mathrm{I}^{-\mathrm{J}^{-}}$and antigenspecific, which appears to suppress both the original Lyt $1^{+}, \mathrm{I}_{-} \mathrm{J}^{+}$inducer, and Lyt $1^{+}$, $\mathrm{I}^{-J^{-}}$helper cells. In agreement with published data showing that $\mathrm{V}_{\mathrm{H}}$ linked genes regulate the inducer-Lyt $123^{+}$interaction [27], the activity of the Lyt $1^{+}$derived $\mathrm{T}_{\mathrm{S}} \mathrm{F}$ is $\mathrm{V}_{\mathrm{H}}$ restricted. The activity of the second factor appears to be limited by $\mathrm{H}-2$ not $\mathrm{V}_{\mathrm{H}}$ genes, though the subregion important in this effect is not yet known. These extremely interesting findings appear to relate the available data on induction in the KLH-GAT-ABA models, and the $\mathrm{H}-2$ restricted effector suppressor factors seen in 


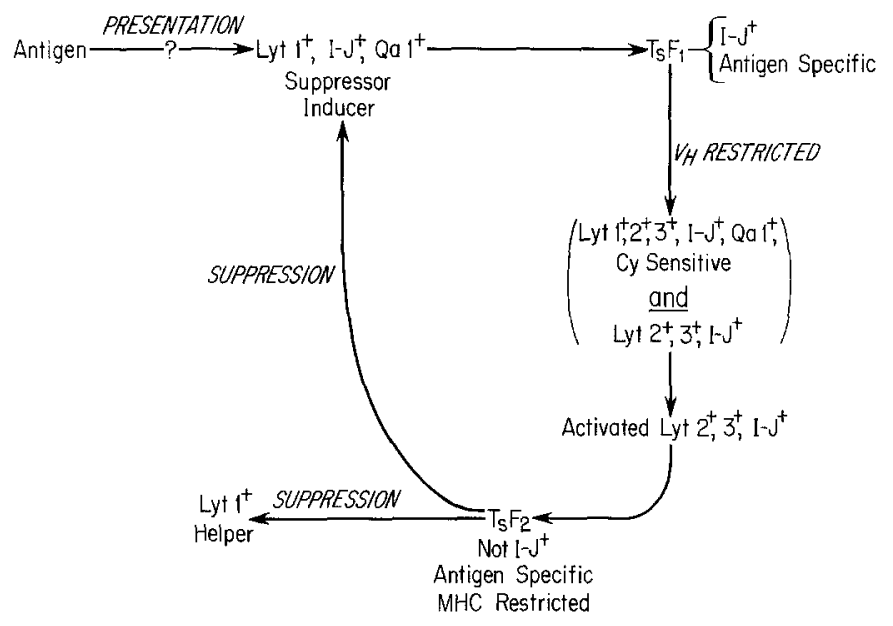

Fig. 4. Suppressor factors in feedback suppression $[17,25-27,46]$. Based largely on detailed studies of the cells involved in feedback suppression, to which has been added recent data on the importance of factors in the $\mathrm{T}$ cell subset interactions

the DNP DTH system. The $\mathrm{V}_{\mathrm{H}}$ restriction is most likely a reflection of the idiotypeanti-idiotype interactions mentioned for $T_{S_{1}}-T_{S_{2}}$ interaction for $A B A-T_{S}$, raising the question of whether the apparent antigen specificity of both the inducing and effector factors in the feedback model is due to complexing of idiotype-bearing material to the antigen (SRBC) used for adsorption.

The last general category of $\mathrm{T}_{\mathrm{S}} \mathrm{F}$ to be discussed concerns effector-type factors (Fig 5), exemplified by protein specific $\mathrm{T}_{\mathrm{S}} \mathrm{F}$ studied in vitro by Kontiainen and Feldman [73], and hapten specific $\mathrm{T}_{\mathrm{S}} \mathrm{F}$ studied by Zembala and Asherson [154, 155], and by Moorhead [87-89]. These materials are distinguished from the inducing materials by acting (without time for $T_{S_{2}}$ generation) directly on primed $T$ cell populations. The lack of any requirement for induction is most clearly seen in the data on in vitro $\mathrm{KLH}-\mathrm{T}_{\mathrm{S}} \mathrm{F}$, which acts on target populations containing only Lyt $1^{+}$cells and B cells, which, lacking Lyt $123^{+}$and $2,3^{+}$cells, cannot serve as a source of pre- $T_{\mathrm{S}_{2}}$ [76]. Among the critical features of certain of these effector materials, namely those active on DTH responses, are (1) the requirement for active immunization to follow $T_{S}$ induction in order for $T_{S} F_{E}$ to be released, (2) the restriction of DNP-T $\mathrm{F}$ activity by $\mathrm{H}-2 \mathrm{~K} / \mathrm{D}$ gene products, and (3) the possible involvement of macrophages as recipients for the $T_{S} F$, following which they release nonspecific suppressive signals. The first feature may indicate a need to restimulate $T_{S_{1}}$ to release $T_{S} F_{1}$ and trigger $T_{S_{2}}$ cells, which once induced need to receive an additional antigenic signal before reaching full activity. The last feature may explain the repeated finding that in certain cases, bystander suppression is seen when both the original suppressing antigen and an irrelevant antigen are administered as a challenge together.

2. Overview of Factor Activity. In the previous section, we have analyzed the salient features of each of the various experimental models, with a particular emphasis on 


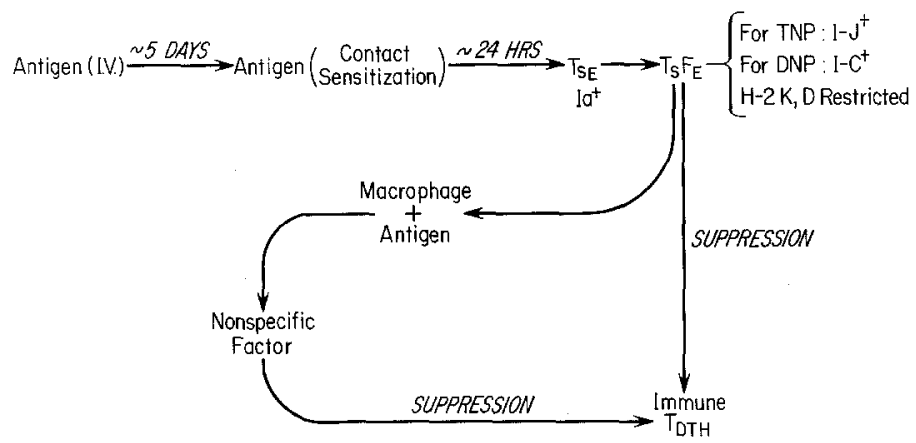

Fig. 5. Effector suppression by factors. Based primarily on observations in contact sensitivity models [2, $3,87-90,106,107,155,156]$

the suppressor factors, for which there is much more information available than for the helper factors. We can attempt to ascertain the degree to which these models can be integrated in a single mechanism of regulation of immune responses by suppressor $\mathrm{T}$ cells, or, alternatively, whether they constitute parallel and separate regulatory pathways.

The most striking feature of virtually all $\mathrm{T}_{\mathrm{S}} \mathrm{F}$ models is that at least one factor in each system plays a crucial role in communication between $T$ cell subsets prior to ultimate suppressor activity. In two experimental systems, it appears that this communication is mediated by idiotype-anti-idiotype interactions. The degree to which this finding is generalizable to all systems needs to be determined, particularly in the Tada model $[123,125-134,138]$ where this issue has not been addressed. In all cases, the result of suppressor factor mediated $\mathrm{T}-\mathrm{T}$ interaction is the generation of true functional suppressor cells (generally termed $\mathrm{T}_{\mathrm{S}_{2}}$ ). One is then tempted to suggest that this induced $\mathrm{T}_{\mathrm{S}_{2}}$ is in fact the $\mathrm{T}_{\mathrm{SE}}$, or ultimate suppressor $\mathrm{T}$ cell as mentioned above.

Among the features which appear, in contrast, to be unique to an individual model, two are of greatest importance. First, in the feedback suppression model, the initiat or cell is a $\mathrm{T}$ cell which does not bear Lyt $2^{+}$markers, in distinction to all other $\mathrm{T}_{\mathrm{S}}$ cell typing data. It is possible, however, that such a cell is also the initial $\mathrm{T}$ cell involved in the pathways in other systems and the source of inducing factor(s). The factor producing cell in the GAT/GT/ABA system has not been Lyt phenotyped and thus the involvement of an Lyt $1^{+}$cell in these or the earliest stages of the Tada model has never been formally ruled out.

A much greater difficulty is the observation of a strict I-J restriction involving factor and target cells in the Tada system, and the absence of such restrictions in all other studies, including those to the same antigen. It must first be noted that the mode of antigen exposure for $\mathrm{T}_{\mathrm{S}}$ induction differs in all these other models. It is unlikely that the I-J restriction seen results from the use of primed target cells for the $\mathrm{T}_{\mathrm{S}} \mathrm{F}$ assay since (1) Tada found $\mathrm{H}-2$ restriction in $\mathrm{KLH}-\mathrm{T}_{\mathrm{S}} \mathrm{F}$ activity tested on primary anti-hapten responses in vivo and (2) the use of secondary responses in vitro or in vivo by others in testing $\mathrm{T}_{\mathrm{S}} \mathrm{F}$ failed to reveal such restrictions. Therefore, if the I-J restriction is related to a particular aspect of Tada's experimental protocol, it 
would appear to be more likely related to the mode of $\mathrm{T}_{\mathrm{S}}$ induction, in particular, to the use of multiple immunizations for generating the $T_{S} F$ producing $T$ cells. Alternatively, it is also possible that the involvement of common (cross-reactive) idiotypes in GAT and ABA responses may somehow obscure I-J restrictions in these latter cases, or that a different dependence upon various subsets of $T_{H}$ cells in the various models might play a crucial role in the importance of I-J restrictions in each case. Whatever the explanation, one is forced to consider the implications of the I-J restriction when seen. As hypothesized by Tada et al., the most likely reason for the matching requirement is that the "acceptor" site for the $T_{S} F$ is determined by I-J coded genes. This can be considered to be due to an inherent "like-like" interaction between identical I-J gene products, or to a unidirectional recognition of one I-J product by another. Given the wealth of data on other $\mathrm{H}-2$ restrictions for $\mathrm{T}$ cell activities which indicate that such restrictions are determined by education for anti-self reactivity in the thymus [86], it is also reasonable to consider a similar meachanism for KLH-T $\mathrm{S}_{\mathrm{S}} \mathrm{F}$. This leads to the same conclusion put forth by Schrader [114], i.e., either the $\mathrm{T}_{\mathrm{S}} \mathrm{F}$ actually has a combining site ( $\mathrm{V}$ region) capable of recognizing haplotype specific determinants of I-J molecules on target $T$ cells, or conversely, the target $T$ cells have such $V$ regions recognizing the I-J coded determinants on the $T_{S} F$. Similar distinctions between these possibilities and genetically preprogrammed I-J: I-J interactions that do not involve $V$ region genes will hopefully be made by experiments using $\mathrm{T}_{\mathrm{S}} \mathrm{F}$ and target $\mathrm{T}$ cells from chimeric mice.

Lastly, one major unresolved issue is whether the so-called inducing factors (produced by $\mathrm{T}_{\mathrm{S}_{1}}$ cells) are truly secreted products with mediator (hormone-like) function. In a majority of cases, the products are obtained by disrupting immune cells. In those cases where $T_{S} F$ is detected in the supernatant of cells kept in culture, the issue of whether this merely reflects receptor shedding and not active secretion has not been adequately investigated. It was attractive to speculate in the early phases of factor investigation that $\mathrm{T}_{\mathrm{S}} \mathrm{F}$ was a secreted regulatory molecule. However, in the light of more recent indications of the involvement of these products in idiotypic regulatory networks, it is just as plausible that they simply represent shed idiotypic structures to which the immune system is exquisitely sensitive. In either case, however, it would seem that the possession of I-J (C) related determinants, which appear to be unique features of suppressor pathways, renders these materials especially able to evoke subsequent $\mathrm{T}$ cell responses.

In summary then, it is apparent that soluble antigen specific products of $\mathrm{T}$ lymphocytes exist which play important roles in both cellular and humoral immune regulation. These factors probably are released in vivo in sufficient quantity to act at a distance, perhaps via macrophages or directly on the relevant target cell. They consist of an MHC (I region) coded portion probably related to biologic effector function, and an antigen binding portion, possibly coded for by $\operatorname{Ig} \mathrm{V}_{\mathrm{H}}$ genes, which is responsible for specificity and the activation of idiotypic networks. For both help and suppression, certain factors act as amplifying signals triggering a second set of $T$ cells to provide a more proximal regulatory signal, again in the form of an antigen specific, MHC coded factor. Such complex pathways both provide for exquisite sensitivity, due to the amplification process, and a series of "fail-safe" check points for regulation, to prevent a defect in a single component from imbalancing the entire 
immune system. Future studies on $\mathrm{T}$ cell factor, particularly homogeneous products of long-term $\mathrm{T}$ cell lines or hybridomas, will provide a more precise picture of their biochemical nature and of the molecular basis for their effector activities, thus bridging the gap between this set of specific lymphocyte products, and the current extensive knowledge of that other set, the B cell derived immunoglobulins.

Acknowledgments. We especially wish to thank our many colleagues who shared their unpublished data during the writing of this manuscript. We also wish to acknowledge the excellent secretarial skills of Terri Greenberg and Harriet Yake. This work was supported by grants AI-14732 and POI CA-14723.

\section{References}

1. Asherson, G.L., Zembala, M., Barnes, R.M.R.: The mechanism of immunological unresponsiveness to picryl chloride and the possible role of antibody mediated depression. Clin. Exp. Immunol. 9, 111 (1971)

2. Asherson, G.L., Zembala, M.: T cell suppression of contact sensitivity in the mouse. III. The role of macrophages and the specific triggering of nonspecific suppression. Eur. J. Immunol. 4, 804 (1974)

3. Asherson, G.L., Zembala, M., Noworolski, J.: The purification of specific anti-picryl T suppressor factor which depresses the passive transfer of contact sensitivity: affinity chromatography on antigen and concanavalin $\mathrm{A}$ sepharose and specific elution with hapten and $\alpha$-methylmannoside. Immunology 85, 1051 (1978)

4. Bach, B.A., Sherman, L., Benacerraf, B. Greene, M.I.: Mechanisms of regulation of cell-mediated immunity. II. Induction and suppression of delayed-type hypersensitivity to azobenzenearsonatecoupled syngeneic cells. J. Immunol. 121, 1460 (1978)

5. Bach, B.A., Greene, M.I., Benacerraf, B., Nisonoff, A.: Mechanisms of regulation of cell-mediated immunity. IV. Azobenzenearsonate-specific suppressor factor(s) bear cross-reactive idiotypic determinants the expression of which is linked to the heavy chain allotype linkage group of genes. $\mathbf{J}$. Exp. Med. 149, 1084 (1979)

6. Basten, A., Miller, J.F.A.P., Johnson, P.: T cell dependent suppression of an anti-hapten antibody response. Transplant. Rev. 26, 130 (1975)

7. Benacerraf, B., Kapp, J.A., Debré, P., Pierce, C.W., de la Croix, F.: The stimulation of specific suppressor $\mathrm{T}$ cells in genetic non-responder mice by linear random coplymers of L-amino acids. Transplant. Rev. 26, 21 (1975)

8. Benacerraf, B., Dorf, M.E.: Genetic control of specific immune responses and immune suppresions by I-region genes. Cold Spring Harbor Symp. Quant. Biol, 41, 465 (1977)

9. Benacerraf, B., Waltenbaugh, C., Théze, J., Kapp, J., Dorf, M.E.: The I region genes in genetic regulation. In: The immune system: Genetics and regulation, Sercarz, E., Herzenberg, L.A., Fox, C.F., eds., p. 363. New York: Academic Press 1977

10. Benacerraf, B., Germain, R.N.: The immune response genes of the major histocompatibility complex. Immunol. Rev. 38, 70 (1978)

11. Binz, H., Wigzell, H.: Shared idiotypic determinants on B and T lymphocytes reactive against the same antigenic determinants. V. Biochemical and serological characteristics of naturally occurring, soluble antigen-binding T-lymphocyte-derived molecules. Scand. J. Immunol. 5, 559 (1976)

12. Binz, H., Wigzell, H.: Antigen binding, idiotypic $\mathrm{T}$ lymphocyte receptors. Contemp. Top Immunobiol. 7, 111 (1977)

13. Black, S.J., Hammerling, G.J., Berek, C., Rajewsky, K., Eichmann, K.: Idiotypic analysis of lymphocytes in vitro. I. Specificity and heterogeneity of B and T lymphocytes reactive with antiidiotypic antibody. J. Exp. Med. 143, 846 (1976)

14. Burnet, F.M.: The clonal selection theory of acquired immunity. Cambridge: Cambridge Press 1959

15. Cantor, H., Weissman, J.: Development and function of subpopulations of thymocytes and $\mathrm{T}$ lymphocytes. Prog. Allergy 20, 1 (1976)

16. Cantor, H., Boyse, E.A.: Lymphocytes as models for the study of mammalian cellular differentiation. Immunol. Rev. 33, 105 (1977)

17. Cantor, H., Hugenberger, J., McVay-Boudreau, L., Eardley, D.D., Kemp, J., Shen, F.W., Gershon, R.K.: Immunoregulatory circuits among $T$ cell sets: identification of a subpopulation of $T$ inducer cells that activates feedback inhibition. J. Exp. Med. 148, 871 (1978) 
18. Chaouat, G.: Suppressor T cells in tolerance to human $\gamma$-globulin: mediation by a specific soluble factor. Cell. Immunol. 36, 1 (1978)

19. Cook, R.G., Vitetta, E.A., Uhr, J.W., Capra, J.D.: Structural studies on the murine Ia alloantigens. $\mathrm{V}$. Evidence that the structural gene for the I-E/C beta polypeptide is encoded within the I-A subregion. J. Exp. Med. 149, 981 (1979)

20. Debre, P., Kapp, J., Dorf, M., Benacerraf, B.: Genetic control of immune suppression. I. Experimental conditions for the stimulation of suppressor cells by the copolymer L-glutamic acid ${ }^{50}$-L-tyrosine ${ }^{50}$ (GT) in nonresponder BALB/c mice. J. Exp. Med. 142, 1436 (1976)

21. Debre, P., Kapp, J.A., Dorf, M.E., Benacerraf, B.: Genetic control of immune suppression. II. H-2 linked dominant genetic control of immune suppression by the random copolymer L-glutamic acidL-tyrosine (GT). J. Exp. Med. 142, 1447 (1975)

22. Debre, P., Waltenbaugh, C., Dorf., M., Benacerraf, B.: Genetic control of specific immune suppresion. III. Mapping of $\mathrm{H}-2$ complex complementing genes controlling immune suppresion by the random copolymer L-glutamic acid ${ }^{50}-$ L-tyrosine ${ }^{50}$ (GT). J. Exp. Med. 144, 272 (1976)

23. Dietz, M., Sy, M-S., Greene, M.I., Nisonoff, A., Benacerraf, B., Germain, R.N.: Idiotypic-antiidiotypic interaction of suppressor T cells modulating immunity to Azobenzenearsenate. Fed. Proc. 39, $571(1980)$

24. Dorf, M.E., Plate, J.M.D., Stimplfing, J.H., Benacerraf, B.: Characterization of immune response and mixed lymphocyte reactions in selected intra-H-2 recombinant strains. J. Immunol. 114, 602 (1975)

25. Eardley, D.D., Hugenberger, J., McVay-Boudreau, L., Shen, F.W., Gershon, R.K., Cantor, H.: Immunoregulatory circuits among $\mathrm{T}$ cell sets. I. $\mathrm{T}$ helper cells induce other $\mathrm{T}$ cell sets to exert feedback inhibition. J. Exp. Med. 147, 1106 (1978)

26. Eardley, D.D., Kemp, J., Shen, F.W., Cantor, H., Gershon, R.K.: Immunoregulatory circuits among $\mathrm{T}$ cell sets: effect of mode of immunization on determining which Ly $1 \mathrm{~T}$ cell sets will be activated. J. Immunol. 122, 1663 (1979)

27. Eardley, D.D., Shen, F.W., Cantor, H., Gershon, R.K.: Genetic control of immunoregulatory circuits: genes linked to the Ig locus govern communication between regulatory $T$ cell sets. J. Exp. Med. 150, 44 (1979)

28. Eichmann, K.: Expression and function of idiotypes on lymphocytes. Adv. Immunol. 26, 195 (1978)

29. Erb, P., Feldmann, M.: Role of macrophages in in vitro ind uction of T-helper cells. Nature $\mathbf{2 5 4 ,} 352$ (1975)

30. Feldmann, M., Basten, A.: Cell interactions in the immune response in vitro. III. Specific collaboration across a cell impermeable membrane. J. Exp. Med. 136, 49 (1972)

31. Feldmann, M., Kontiainen, S.: Suppressor cell induction in vitro. II. Cellular requirements of suppressor cell induction. Eur. J. Immunol. 6, 302 (1975)

32. Feldmann, M., Beverly, P.C.L., Woody, J., McKenzie, I.F.C.: T-T interactions in the induction of suppressor and helper $\mathrm{T}$ cells: analysis of membrane phenotype of precursor and amplifier cells. J. Exp. Med. 145, 793 (1977)

33. Feldman, M., Baltz, M., Erb, P., Howie, S., Kontiainen, S., Woody, J.: A comparison of I region associated factors involved in antibody production. In: The immune system: Genetics and regulation, Sercarz, E., Herzenberg, L.A., Fox, C.F., eds., p. 383. New York: Academic Press 1977

34. Feldmann, M., Baltz, M., Erb, P., Howie, S., Kontiainen, S., Woody, J., Zwaifler, N.: A comparison of I region associated factors involved in antibody production. Prog. Immunol. 3, 331 (1977)

35. Fujimoto, S., Greene, M., Sehon, A.H.: Immunosuppressor T cell in tumor-bearing hosts. Immunol. Commun. 4, 201 (1975)

36. Fujimoto, S., Greene, M.I., Sehon, A.H.: Regulation of the immune response to tumor antigens. I. Immunosuppressor cells in tumor-bearing hosts. J. Immunol. 116, 791 (1976)

37. Fujimoto, S., Greene, M.I., Sehon, A.H.: Regulation of the immune response to tumor antigens. II. The nature of immunosuppressor cells in tumor-bearing hosts. J. Immunol. 116, 800 (1976)

38. Germain, R.N.: Antigen-specific T cell suppressor factors - Mode of action. Lymphokine Reports (in press, 1980)

39. Germain, R.N., Theze, J., Kapp, J.A., Benacerraf, B.: Antigen-specific T-cell-mediated suppression. I. Induction of L-glutamic acid ${ }^{60}$-L-alanine ${ }^{30}$-L-tyrosine ${ }^{10}$ specific suppressor $\mathrm{T}$ cells in vitro requires both antigen-specific T-cell suppressor factor and antigen. J. Exp. Med. 147, 123 (1978) 
40. Germain, R.N., Theze, J., Waltenbaugh, C., Dorf, M.E., Benacerraf, B.: Antigen-specific T cellmediated suppression. II. In vitro induction by I-J-coded L-glutamic acid ${ }^{50}$-L-tyrosine ${ }^{50}(\mathrm{GT})$ specific $T$ cell suppressor factor $\left(\mathrm{GT}-\mathrm{T}_{\mathrm{S}} \mathrm{F}\right)$ of suppressor $\mathrm{T}$ cells $\left(\mathrm{T}_{\mathrm{S} 60^{2}}\right)$ bearing distinct I-J determinants. J. Immunol. 121, 601 (1978)

41. Germain, R.N., Benacerraf, B.: Antigen specific T cell-mediated suppression. III. Induction of antigen-specific suppressor $T$ cells $\left(T_{S_{2}}\right)$ in L-glutamic acid ${ }^{60}-\mathrm{L}$-alanine ${ }^{30}-\mathrm{L}$-tyrosine ${ }^{10}(\mathrm{GAT})$ responder mice by nonresponder derived GAT-suppressor factor $\left(G A T-T_{S} F\right)$. J. Immunol. 121, 608 (1978)

42. Germain, R.N., Ju, S-T., Kipps, T.J., Benacerraf, B., Dorf, M.E.: Shared idiotypic determinants on antibodies and T-cell-derived suppressor factor specific for the random terpolymer L-glutamic acid $^{60}$-L-alanine ${ }^{30}$-L-tyrosine ${ }^{10}$. J. Exp. Med. 149, 613 (1979)

43. Germain, R.N., Waltenbaugh, C., Benacerraf, B.: Antigen-specific T cell mediated suppression. V. $\mathrm{H}-2$ linked genetic control of distinct antigen-specific defects in the production and activity of $\mathrm{L}$ glutamic acid ${ }^{50}-\mathrm{L}-$ tyrosine $^{50}$ suppressor factor $\left(\mathrm{GT}-\mathrm{T}_{\mathrm{S}} \mathrm{F}\right)$. J. Exp. Med. (in press, 1980)

44. Gershon, R.K., Maurer, P.H., Merryman, C.F.: A cellular basis for genetically controlled immunologic unresponsiveness in mice: Tolerance induction in T cells. Proc. Natl. Acad. Sci. USA 70, 250 (1973)

45. Gershon, R.K.: T cell control of antibody production. Contemp. Top. Immunobiol. 3, 1 (1974)

46. Gershon, R.K., Cantor, H.: Unpublished observation (1979)

47. Gershon, R.K., Eardley, D.D., Naidorf, K.F., Ptak, W.: The hermaphrocyte: a suppressor-helper T cell. Cold Spring Harb. Symp. Quant. Biol. 41, 85 (1976)

48. Greene, M.I., Fujimoto, S., Sehon, A.H.: Regulation of the immune response to tumor antigens. III. Characterization of thymic suppressor factor(s) produced by tumor-bearing hosts. J. Immunol. 119, $757(1977)$

49. Greene, M.I., Pierres, A., Dorf, M., Benacerraf, B.: The I-J subregion codes for determinants on suppressor factor(s) which limit the contact sensitivity response to picryl chloride. J. Exp. Med. 146, $293(1977)$

50. Greene, M.I., Bach, B.A., Benacerraf, B.: Mechanisms of regulation of cell-mediated immunity. III. The characterization of azobenzenearsonate specific suppressor T-cell-derived suppressor factors. J. Exp. Med. 149, 1069 (1979)

51. Howie, S.: In vitro studies on H-2 linked unresponsiveness to synthetic polypeptide antigens. II. Induction of suppressor cells in both responsive and unresponsive mice to (T, G)-A - L and $\mathrm{GAT}^{10}$. Immunology 32, 301 (1977)

52. Howie, S., Feldmann, M.: In vitro studies on $\mathrm{H}-2$ linked unresponsiveness to synthetic polypeptides. III. Production of an antigen-specific T helper cell factor to (T, G)-A - L. Eur. J. Immunol. 7, 417 (1977)

53. Howie, S., Feldmann, M.: Immune response (Ir) genes express at macrophage-B lymphocyte interactions. Nature 273, 664 (1978)

54. Howie, S., Parish, C.R., David, C.S., McKenzie, I.F.C., Maurer, P.H., Feldmann, M.: Serological analysis of antigen-specific helper factors specific for poly-L-(Tyr, Glu)-poly-DL-ala - poly-L-Lys $[(T, G)-A-L]$ and L-Glu ${ }^{60}-\mathrm{L}-\mathrm{Ala}^{30}-\mathrm{L}-\mathrm{Tyr}^{10}$ (GAT). Eur. J. Immunol. 9, 501 (1979)

55. Isac R., Mozes, E., Taussig, M.: Antigen-specific T-cell factors in the immune response to poly (Tyr, Glu)-poly (Pro)-poly (Lys). Immunogenetics 3, 409 (1976)

56. Isac, R., Mozes, E.: Antigen-specific T cell factors: A fine analysis of specificity. J. Immunol. 118, 584 (1977)

57. Isac, R., Dorf, M.E., Mozes, E.: The T-cell factor specific for poly (Tyr, Glu)-poly (Pro)-poly (Lys) is an I-region-gene product. Immunogenetics 5, 467 (1977)

58. Ishizaka, K., Adachi, T.: Generation of specific helper cells and suppressor cells in vitro for the IgE and IgG antibody responses. J. Immunol. 117, 40 (1976)

59. Jerne, N.K.: Towards a network theory of the immune response. Ann. Immunol. (Paris) 125C, 373 (1974)

60. Jones, T.B., Kaplan, A.M.: Immunologic tolerance to HGG in mice. I. Suppression of the HGG response in normal mice with spleen cells or a spleen cell lysate from tolerant mice. J. Immunol. 118, $1880(1977)$

61. Ju, S-T., Kipps, T.J., Theze, J., Benacerraf, B., Dorf, M.E.: Idiotypic analysis of anti-GAT antibodies. I. Presence of common idiotypic specificities in both responder and nonresponder mice. J. Immunol. 121, 1034 (1978) 
62. Ju, S-T., Benacerraf, B., Dorf, M.E. Idiotypic analysis of anti-GAT antibodies: interstrain and interspecies idiotypic cross-reactions. Proc. Natl. Acad. Sci. USA 75, 6192 (1978)

63. Ju, S-T., Dorf, M.E., Benacerraf, B.: Idiotypic analysis of anti-GAT antibodies. III. Determinant specificity and immunoglobulin class distribution of CGAT idiotype. J. Immunol. 122, 1054 (1979)

64. Ju, S-T., Dorf, M.E.: Idiotypic analysis of antibodies against the terpolymer L-glutamic acid ${ }^{60}$-Lalanine ${ }^{30}$-L-tyrosine ${ }^{10}$ (GAT). IV. Induction of CGAT idiotype following immunization with various synthetic polymers containing glutamic acid and tyrosine. Eur. J. Immunol. 9, 553 (1979)

65. Kapp, J.A.: Immunosuppressive factor(s) extracted from lymphoid cells of nonresponder mice primed with L-glutamic acid ${ }^{60}$-L-alanine ${ }^{30}$-L-tyrosine ${ }^{10}$ (GAT). IV. Lack of strain restriction among allogeneic, nonresponder donors and recipients. J. Exp. Med. 147, 997 (1978)

66. Kapp, J.A., Araneo, B.A.: Interactions of macrophages and T cells in the development of antibody and proliferative responses. In: Macrophage regulation of immunity, Unanue, E.R., Rosenthal, A.S., eds., p. 141. New York: Academic press 1980

67. Kapp, J.A., Pierce, C.W., Benacerraf, B.: Genetic control of immune response in vitro. I. Development of primary and secondary plaque-forming cell responses to the random terpolymer Lglutamic acid ${ }^{60}$-L-alanine ${ }^{30}-$ L-tyrosine ${ }^{10}$ (GAT) by mouse spleen cells in vitro. J. Exp. Med. 138, 1107 (1973)

68. Kapp, J.A., Pierce, C.W., Schlossman, S., Benacerraf, B.: Genetic control of immune responses in vitro. V. Stimulation of suppressor T cells in nonresponder mice by the terpolymer L-glutamic acid $^{60}$-L-alanine ${ }^{30}$-L-tyrosine ${ }^{10}$ (GAT). J. Exp. Med. 140, 648 (1974)

69. Kapp, J.A., Pierce, C.W., DeLaCroix, F., Benacerraf, B.: Immunosuppressive factor(s) extracted from lymphoid cells of nonresponder mice primed with L-glutamic acid ${ }^{60}$-L-alanine ${ }^{30}$-Ltyrosine $^{10}$ (GAT). Activity and antigenic specificity. J. Immunol. 116, 305 (1976)

70. Kapp. J.A., Pierce, C.W., Benacerraf, B.: Immunosuppressive factor(s) extracted from lymphoid cells of nonresponder mice primed with L-glutamic acid ${ }^{60}$-L-alanine ${ }^{30}$-Ltyrosine ${ }^{10}$ (GAT). II. Cellular source and effect on responder and nonresponder mice. J. Exp. Med. 145, 828 (1977)

71. Karjalainen, K., Mäkelä, O.: A mendelian idiotype is demonstrable in the heteroclitic anti-NP antibodies of the mouse. Eur. J. Immunol. 8, 105 (1978)

72. Katz, D.H., Dorf, M.E., Benacerraf, B.: Control of T-lymphocyte and B-lymphocyte activation by two complementing Ir-GL $\varnothing$ immune response genes. J. Exp. Med. 143, 906 (1976)

73. Kontiainen, S., Feldmann, M.: Induction of specific helper cells in vitro. Nature 245, 285 (1973)

74. Kontiainen, S., Feldmann, M. Suppressor cell induction in vitro. I. Kinetics of induction of antigenspecific suppressor cells. Eur. J. Immunol. 6, 296 (1976)

75. Kontiainen, S., Feldmann, M.: Suppressor cell induction in vitro. III. Antigen-specific suppression by supernatants of suppressor cells. Eur. J. Immunol. 7, 310 (1977)

76. Kontianen, S., Feldmann, M.: Suppressor cell induction in vitro. IV. Target of antigen-specific suppressor factor and its genetic relationships. J. Exp. Med. 147, $110(1978)$

77. Kontiainen, S., Simpson, E., Bohrer, E., Beverly, P.C.L., Herzenberg, L.A., Fitzpatrick, W.C., Vogt, P., Torano, A., McKenzie, I.F.C., Feldmann, M.: T-cell lines producing antigen-specific suppressor factor. Nature 274, 477 (1978)

78. Kontiainen, S., Howie, S., Maurer, P.H., Feldmann, M.: Suppressor cell induction in vitro. VI. Production of suppressor factors to synthetic polypeptides GAT and (T, G)-A-L from cells of responder and nonresponder mice. J. Immunol. 122, 253 (1979)

79. Krawinkel, U., Cramer, M., Imanishi-Kari, T., Jack, R.S., Rajewsky, K., Mäkelä, O.: Isolated hapten-binding receptors of sensitized lymphocytes. I. Receptors from nylon wool-enriched mouse $\mathrm{T}$ lymphocytes lack serological markers of immunoglobulin constant domains but express heavy chain variable portions. Eur. J. Immunol. 7, 566 (1977)

80. Lewis, G.K., Goodman, J.W.: Purification of functional, determinant-specific, idiotype-bearing murine T cells. J. Exp. Med. 148, 915 (1978)

81. Marrack, P., Kappler, J.W.: The role of $\mathrm{H}-2$ linked genes in helper T cell function. III. Expression of immune response genes for trinitrophenyl conjugates of poly-L-(Tyr, Glu)-poly-D, L-Ala-poly-LLys in B cells and macrophages. J. Exp. Med. 147, 1596 (1978)

82. McDevitt, H.O., Tyan, M.L.: Genetic control of the antibody response in inbred mice. Transfer of response by spleen cells and linkage to the major histocompatibility (H-2) locus. J. Exp. Med. 128, 1 (1968)

83. McDevitt, H.O., Benacerraf, B.: Genetic control of specific immune responses. Adv. Immunol. 11, $31(1969)$ 
84. Miller, S.D., Sy, M.S., Claman, H.N.: H-2 restriction of suppressor T-cell induction by haptenmodified lymphoid cells in tolerance to 1-fluoro-2, 4-dinitrobenzene contact sensitivity. J. Exp. Med. 145, 1071 (1977)

85. Möller, G., ed.: Role of macrophages in the immune response. Immunol. Rev. 40, (1978)

86. Möller, G., ed.: Acquisition of the T cell repertoire. Immunol. Rev. 42, (1978)

87. Moorhead, J.W.: Soluble factors in tolerance and contact sensitivity to 2,4-dinitrofluorobenzene in mice. I. Suppression of contact sensitivity by soluble suppressor factor released in vitro by lymph node cell populations containing specific suppressor cells. J. Immunol. 119, 315 (1977)

88. Moorhead, J.W.: Soluble factors in tolerance and contact sensitivity to DNFB in mice. II. Genetic requirements for suppression of contact sensitivity by soluble suppressor factor. J. Immunol. 119, $1773(1977)$

89. Moorhead, J.W.: Soluble factors in tolerance and contact sensitivity to 2,4-dinitrofluorobenzene in mice. III. Histocompatibility antigens associated with the hapten dinitrophenol serve as target molecules on 2,4-dinitrofluorobenzene immune T cells for soluble suppressor factor. J. Exp. Med. 150, 1432 (1979)

90. Moorhead, J.W.: Personal communication (1979)

91. Mozes, E.: Expression of immune response (Ir) genes in T and B cells. Immunogenetics 2, 397 (1975)

92. Mozes, E., Shearer, G.M.: Genetic control of immune responses. Curr. Top. Microbiol. Immunol. 59, $167(1972)$

93. Mozes, E., Isac, R., Taussig, M.J.: Antigen-specific T-cell factors in the genetic control of the immune response to poly (tyr-glu)-poly D, $\mathbf{L}$ ala - poly lys. Evidence for T- and B-cell defects in SJL mice. J. Exp. Med. 141, 703 (1975)

94. Mozes, E., Haimovich, J.: Antigen specific T-cell helper factor cross-reacts idiotypically with antibodies of the same specificity. Nature 278, 56 (1979)

95. Munro, A.J., Taussig, M.J., Campbell, R., Williams, H., Lawson, V.: Antigen-specific T-cell factor in cell cooperation: physical properties and mapping in the left-hand (K) half of H-2. J. Exp. Med. 140, 1579 (1979)

96. Munro, A.J., Taussig, M.J.: Two genes in the major histocompatibility complex control immune response. Nature 256, 103 (1975)

97. Munro, A.J., Taussig, M.J.: Complementation of immune response genes for (T, G)-A - L. Nature 269, $355(1977)$

98. Murphy, D.B., Herzenberg, L.A., Okumura, K., Herzenberg, L.A., McDevitt, H.O.: A new I subregion (I-J) marked by a locus (Ia-4) controlling surface determinants on suppressor $\mathrm{T}$ lymphocytes. J. Exp. Med. 144, 699 (1976)

99. Nisonoff, A., Ju, S-T., Owen, F.L.: Studies of structure and immunosuppression of a cross-reactive idiotype in strain A mice. Immunol. Rev. 34, 89 (1977)

100. Okumura, K., Tada, T.: Regulation of homocytotropic antibody formation in the rat. IX. Further characterization of the antigen-specific inhibitory $\mathrm{T}$ cell factor in hapten-specific homocytotropic antibody response. J. Immunol. 112, 783 (1974)

101. Okumura, K., Takemori, T., Tokuhisa, T., Tada, T.: Specific enrichment of the suppressor T-cell bearing I-J determinants. Parallel functional and serological characterizations. J. Exp. Med. 146, $1234(1977)$

102. Okumura, K., Tada, T.: The role of antigen specific T cells factors in the immune response. Adv. Immunol. 28, 1 (1980)

103. Perry, L., Benacerraf, B., Greene, M.I.: Regulation of the immune response to tumor antigens. IV. Tumor antigen-specific suppressor factor(s) bear I-J determinants and induce suppressor T cells in vivo. J. Immunol. 121, 2144 (1978)

104. Pierres, M., Germain, R.N.: Antigen-specific T cell-mediated suppression. IV. Role of macrophages in generation of $\mathrm{L}$-glutamic acid ${ }^{60}$-L-alanine ${ }^{30}$-L-tyrosine ${ }^{10}$ (GAT)-specific suppressor $\mathrm{T}$ cells in responder mouse strains. J. Immunol. 121, 1306 (1978)

105. Pierres, M., Benacerraf, B., Germain, R.N.: Antigen-specific T cell-mediated suppresion. VI. Properties of in vitro generated L-glutamic acid ${ }^{60}$-L-alanine ${ }^{30}-\mathrm{L}_{\text {-tyrosine }}{ }^{10}$ (GAT-specific $\mathrm{T}$ suppressor factor(s) (GAT-T $\mathrm{T}_{\mathrm{S}} \mathrm{F}$ ) in responder mouse strains. J. Immunol. 123, 2756 (1979)

106. Ptak, W., Naidorf, K.F., Gershon, R.K.: Interference with the transmission of $T$ cell-derived messages by macrophage membranes. J. Immunol. 119, 444 (1977)

107. Ptak, W., Zembala, M., Hanczakowski-Rewicka, M., Asherson, G.L.: Nonspecific macrophage 
suppressor factor: its role in the inhibition of contact sensitivity to picryl chloride by specific $\mathrm{T}$ suppressor factor. Eur. J. Immunol. 8, 645 (1978)

108. Rich, S.S., Rich, R.R.: Regulatory mechanisms in cell-mediated immune responses. I. Regulation of mixed lymphocyte reactions by alloantigen-activated thymus-derived lymphocytes. J. Exp. Med. 140, 1588 (1974)

109. Rich, S.S., Rich, R.R.: Regulatory mechanisms in cell-mediated immune responses. II. A genetically restricted suppressor of mixed lymphocyte reactions released by alloantigen-activated spleen cells. J. Exp. Med. 142, 1391 (1975)

110. Rich, S.S., Rich, R.R.: Regulatory mechanisms in cell-mediated immune responses. III. I-region control of suppressor cell interaction with responder cells in mixed lymphocyte reactions. J. Exp. Med. 143, 672 (1976)

111. Rich, S.S., Rich, R.R.: Regulatory mechanisms in cell-mediated immune responses. I.V. Expression of a receptor for mixed lymphocyte reaction suppressor factor on activated T lymphocytes. J. Exp. Med. 144, 1214 (1976)

112. Rich, S.S., Orson, F.M., Rich, R.R.: Regulatory mechanisms in cell-mediated immune responses. VI. Interaction of $\mathrm{H}-2$ and non-H-2 genes in elaboration of mixed leukocyte reaction suppressor factor. J. Exp. Med. 146, $1221(1977)$

113. Rich, S.S., David, C.S., Rich, R.R.: Regulatory mechanisms in cell-mediated immune responses. VII. Presence of I-C subregion determinants on mixed leukocyte reaction suppressor factor. J. Exp. Med. 149, 114 (1979)

114. Schrader, J.W.: Nature of the T cell receptor. Scand. J. Immunol. 10, 387 (1979)

115. Schwartz, R.H., Solinger, A.M., Ultee, M.E., Margoliash, E., Yano, A., Stimpfling, J.H., Chen, C., Merryman, C.F., Maurer, P.H., Paul, W.E.: Ir-gene complementation in the murine T-lymphocyte proliferative response. In: T and B lymphocytes: Recognition and function, Bach, F., Vitetta, E.S., Bonavida, B., Fox, C.F., eds., p. 261. New York: Academic Press 1980

116. Sela, M., Fuchs, S., Arnon, R.: Studies on the chemical basis of the antigenicity of proteins. 5. Synthesis, characterization, and immunogenicity of some multichain and linear polypeptides containing tyrosine. Biochem. J. 85, 223 (1962)

117. Shearer, G.M., Schmitt-Verhulst, A.M.: Major histocompatibility complex restricted cell-mediated immunity. Adv. Immunol. 25, 55 (1977)

118. Singer, A., Cowing, C., Hathcock, K.S., Dickler, H.B., Hodes, R.J.: Cellular and genetic control of antibody responses in vitro. III. Immune response gene regulation of accessory cell function. J. Exp. Med. 147, 1611 (1978)

119. Singer, A., Hathcock, K.S., Hodes, R.J.: Cellular and genetic control of antibody responses. V. Helper T-cell recognition of H-2 determinants on accessory but not B cells. J. Exp. Med. 149, 1208 (1979)

120. Smith, S.M., Ness, D.B., Talcott, J.A., Grumet, F.C.: Genetic control of IgM responses to (T, G)A-L: H-2 and Ig-1 linkage. Immunogenetics 4, 221 (1977)

121. Sy, M-S., Brown, A., Nisonoff, A., Gottlieb, P., Benacerraf, B., Greene, M.I.: Analysis of suppressor factor(s) $\left(\mathrm{T}_{\mathrm{S}} \mathrm{F}\right)$ which inhibit azobenezenearsonate (ABA) specific DTH. Fed. Proc. (in press, 1980)

122. Sy, M-S., Dietz, M.H., Nisonoff, A., Germain, R.N., Benacerraf, B., Greene, M.I.: Antigen and receptor driven regulatory mechanisms. IV. Idiotype bearing suppressor $T$ cell factor $\left(T_{S} F\right)$ induces second order suppressor cells $\left(\mathrm{T}_{\mathrm{S}_{2}}\right)$ which express anti-idiotypic receptors. J. Exp. Med. (in press, 1980)

123. Tada, T.: Regulation of the antibody response by $\mathrm{T}$ cell products determined by different I subregions. In: Regulation of the immune system, Sercarz, E., Herzenberg, L., eds. p. 345. New York: Academic Press 1977

124. Tada, T., Okumura, K., Taniguchi, M.: Regulation of homocytotropic antibody formation in the rat. VII. An antigen-specific T cell factor that regulates anti-hapten homocytotropic antibody response. J. Immunol. 111, 952 (1973)

125. Tada, T., Taniguchi, M., Takemori, T.: Properties of primed suppressor T cells and their products. Transplant. Rev. 26, 106 (1975)

126. Tada, T., Taniguchi, M., David, C.S.: Properties of the antigen-specific suppressive T-cell factor in the regulation of antibody response of the mouse. IV. Special subregion assignment of the gene(s) that codes for the suppressive T-cell factor in the H-2 histocompatibility complex. J. Exp. Med. 144, $713(1976)$ 
127. Tada, T., Taniguchi, M., David, C.S.: Suppressive and enhancing T cell factors as I region gene products: properties and subregion assignment. Cold Spring Harbor Symp. Quant. Biol. 41, 119 (1977)

128. Tada, T., Takemori, T., Okumura, K., Nonaka, M., Tokuhisa, T.: Two distinct types of helper T cells involved in the secondary antibody response: independent and synergistic effects of $\mathrm{Ia}^{-}$and $\mathrm{Ia}^{+}$ helper T cells. J. Exp. Med. 147, 446 (1978)

129. Tada, T., Taniguchi, M., Okumura, K.: Multiple MHC loci controlling lymphocyte interactions. J. Supramol. Struct. 3, 236 (1979)

130. Takemori, T., Tada, T.: Selective roles of thymus-derived lymphocytes in the antibody response. II. Preferential suppresion of high affinity antibody-forming cells by carrier-primed suppressor $\mathrm{T}$ cells. J. Exp. Med. 140, 253 (1974)

131. Takemori, T., Tada, T.: Properties of antigen-specific suppressive T-cell factor in the regulation of antibody response of the mouse. I. In vivo activity and immunochemical characterizations. J. Exp. Med. 142, 1241 (1975)

132. Taniguchi, M., Takei, I., Tada, T.: Functional and molecular organization of an antigen - specific suppressor factor from a $\mathrm{T}$ cell hybridoma. Nature 283, 227 (1980)

133. Taniguchi, M., Hayakawa, K., Tada, T.: Properties of antigen-specific suppressive $\mathrm{T}$ cell factor in the regulation of antibody response of the mouse. II. In vitro activity and evidence for the I region gene product. J. Immunol. 116, 542 (1976)

134. Taniguchi, M., Tada, T., Tokuhisa, T.: Properties of the antigen-specific suppressive T-cell factor in the regulation of antibody response of the mouse. III. Dual gene control of the T-cell-mediated suppression of the antibody response. J. Exp. Med. 144, 20 (1976)

135. Taniguchi, M., Miller, J.F.A.P.: Enrichment of specific suppressor T cells and characterization of their surface markers. J. Exp. Med. 146, 1450 (1977)

136. Taniguchi, M., Miller, J.F.A.P.: Specific suppressive factors produced in hybridomas derived from the fusion of enriched suppressor T cells and a T lymphoma cell line. J. Exp. Med. 148, 373 (1978)

137. Taniguchi, M., Miller, J.F.A.P.: Specific suppression of the immune response by a factor obtained from spleen cells of mice tolerant to human $\gamma$-globulin. J. Immunol. 120, 21 (1978)

138. Taniguchi, M., Saito, T., Tada, T.: Antigen-specific suppressive factor produced by a transplantable I-J bearing T cell hybridoma. Nature 278, 555, (1979)

139. Taussig, M.J.: T cell factor which can replace the activity of T cells in vivo. Nature 248, 234 (1974)

140. Taussig, M.J., Munro, A.J.: Removal of specific cooperative T cell factor by anti-H-2 but not by anti-Ig sera. Nature 251, 63 (1974)

141. Taussig, M.J., Mozes, E., Isac, R.: Antigen-specific thymus cell factors in the genetic control of the immune response to poly-(tyrosyl, glutamyl)-poly-D, L-alanyl-poly-lysyl. J. Exp. Med. 140, 301 (1974)

142. Taussig, M.J., Munro, A.J., Campell, R., David, C.S., Staines, N.A.: Antigen-specific T-cell factor in cell cooperation. Mapping within the I region of the $\mathrm{H}-2$ complex and ability to cooperate across allogeneic barriers. J. Exp. Med. 142, 694 (1975)

143. Taussig, M., Corvalan, J.R.F., Binns, R.M., Holliman, A.: Production of an H-2 related suppressor factor by a hybrid T cell line. Nature 277, 305 (1979)

144. Taussig, M., Holliman, A.: Structure of an antigen specific suppressor factor produced by a hybrid T cell line. Nature 277, 308 (1979)

145. Theze, J., Kapp, J.A., Benacerraf, B.: Immunosuppressive factor(s) extracted from lymphoid cells of nonresponder mice primed with L-glutamic acid ${ }^{60}$-L-alanine ${ }^{30}$-L-tyrosine ${ }^{10}$ (GAT). III. Immunochemical properties of the GAT-specific suppressive factor. J. Exp. Med. 145, 839 (1977)

146. Theze, J., Waltenbaugh, C., Dorf, M.E., Benacerraf, B.: Immunosuppressive factor(s) specific for L-glutamic acid ${ }^{50}-\mathrm{L}$-tyrosine ${ }^{50}$ (GT). II. Presence of I-J determinants on the GT-suppressive factor. J. Exp. Med. 146, 287 (1977)

147. Theze, J., Waltenbaugh, C., Germain, R.N., Benacerraf, B.: Immunosuppressive factor(s) specific for L-glutamic acid ${ }^{50}-$-tyrosine ${ }^{50}$ (GT). IV. In vitro activity and immunochemical properties. Eur. J. Immunol. 7, 705 (1977)

148. Theze, J., Sommé, G.: Genetic control of the immune response to the terpolymer L-glutamic acid ${ }^{60}$. L-alanine ${ }^{30}-\mathrm{L}-\mathrm{tyrosine}^{10}$ (GAT). II. Characterization of a cross-reactive idiotype associated with anti-GAT antibodies from responder and nonresponder mice. Eur. J. Immunol. 9, 294 (1979)

149. Tokuhisa, T., Taniguchi, M., Okumura, K., Tada, T.: An antigen-specific I region gene product that augments the antibody response. J. Immunol. 120, 414 (1978) 
150. Waltenbaugh, C., Debre, P., Theze, J., Benacerraf, B.: Immunosuppressive factor(s) specific for L-glutamic acid ${ }^{50}$-L-tyrosine ${ }^{50}$ (GT). I. Production, characterization, and lack of $\mathrm{H}-2$ restriction for activity in recipient strain. J. Immunol. 118, 2073 (1977)

151. Waltenbaugh, C., Benacerraf, B.: Specific suppressor extract stimulates the production of suppressor T cells. In: Proceedings of the Third. Ir Gene Workshop, McDevitt, H.O., ed., p. 549. New York: Academic Press 1978

152. Waltenbaugh, C., Theze, J., Kapp, J.A., Benacerraf, B.: Immunosuppressive factor(s) specific for L-glutamic acid ${ }^{50}$-L-tyrosine ${ }^{50}$ (GT). III. Generation of suppressor T cells by a suppressive extract derived from GT-primed lymphoid cells. J. Exp. Med. 146, 970 (1977)

153. Weinberger, J.Z., Greene, M.l., Benacerraf, B., Dorf, M.: Hapten-specific T cell responses to 4-hydroxy-3-nitrophenylacetyl. I. Genetic control of delayed type hypersensitivity by $\mathrm{V}_{\mathrm{H}}$ and I-A region genes. J. Exp. Med. 149, 1336 (1979)

154. Zembala, M., Asherson, G.L.: Depression of the T cell phenomenon of contact sensitivity by T cells from unresponsive mice. Nature 244, 227 (1973)

155. Zembala, M., Asherson, G.L.: T cell suppression of contact sensitivity in the mouse. II. The role of soluble suppressor factor and its interaction with macrophages. Eur. J. Immunol. 4, 799 (1974)

156. Zembala, M., Asherson, G.L., Mayhew, B., Krejci, J.: In vitro absorption and molecular weight of specific T cell suppressor factor. Nature 253, 72 (1975)

\section{Note Added in Proof}

Recent data obtained in the ABA suppression model reveal that $T_{s 2}$ produce a suppressor factor $\left(\mathrm{T}_{\mathrm{s}} \mathrm{F}_{2}\right)$ which fails to act across H-2 differences. Given this finding, it is possible to synthesize the schemes shown in Figs. 2-5 into a general model: $\mathrm{Ag} \longrightarrow \mathrm{T}_{\mathrm{s} 1} \longrightarrow \mathrm{T}_{\mathrm{s}} \mathrm{F}_{1}$

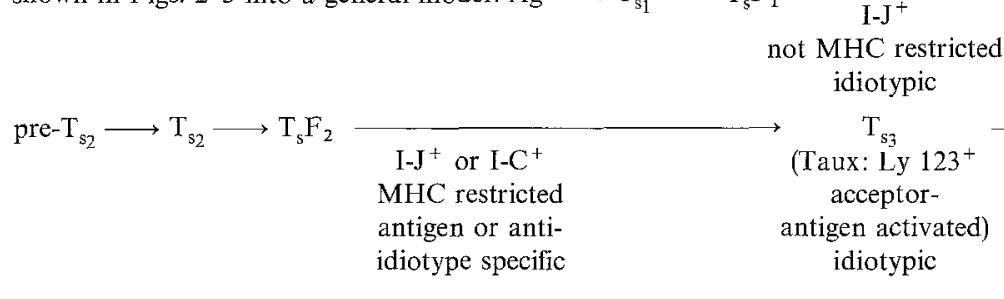

$\longrightarrow$ nonspecific suppressor mediator.

Thus, the previous data on inducing factors in $A B A$ and GAT models defined $T_{s_{t}}-T_{s 2}$ interaction, while data on I-J restricted KLH-T $\mathrm{F}$ and DNP DTH suppressor factor defined $\mathrm{T}_{\mathrm{s}_{2}}-\mathrm{T}_{\mathrm{s}_{3}}\left(\mathrm{~T}_{\mathrm{aux}}\right)$ interaction, accounting for the differences observed in MHC restriction phenomena. 